NBER WORKING PAPER SERIES

\title{
ON THE LIFECYCLE DYNAMICS OF VENTURE-CAPITAL- AND NON-VENTURE-CAPITAL-FINANCED FIRMS
}

\author{
Manju Puri \\ Rebecca Zarutskie \\ Working Paper 14250 \\ http://www.nber.org/papers/w14250
NATIONAL BUREAU OF ECONOMIC RESEARCH
1050 Massachusetts Avenue
Cambridge, MA 02138 \\ August 2008
}

We thank seminar participants at the Center for Economics Studies, Columbia University, Duke University, Harvard Business School, London Business School, Massachusetts Institute of Technology, National Institute of Public Finance and Policy, New Delhi, the New York Fed, the University of Illinois, UrbanaChampaign, the Western Finance Association 2007 meeting, the European Finance Association 2007 meeting and the 4th Annual Conference on Corporate Finance at Washington University for comments and suggestions. We thank Kirk White for his diligent assistance with the data and for helpful comments. Jie Yang and Shouyue Yu provided excellent research assistance. The research in this paper was conducted while the authors were Special Sworn researchers of the U.S. Census Bureau at the Triangle Census Research Data Center. Research results and conclusions expressed are those of the authors and do not necessarily reflect the views of the Census Bureau. This paper has been screened to insure that no confidential data are revealed. Please address correspondence to Puri or Zarutskie at Fuqua School of Business, Duke University, Box 90120, Durham, North Carolina 27708. Puri can be reached at mpuri@duke.edu; Zarutskie can be reached at rebeccaz@duke.edu. The views expressed herein are those of the author(s) and do not necessarily reflect the views of the National Bureau of Economic Research.

NBER working papers are circulated for discussion and comment purposes. They have not been peerreviewed or been subject to the review by the NBER Board of Directors that accompanies official NBER publications.

(C) 2008 by Manju Puri and Rebecca Zarutskie. All rights reserved. Short sections of text, not to exceed two paragraphs, may be quoted without explicit permission provided that full credit, including $\odot$ notice, is given to the source. 
On the Lifecycle Dynamics of Venture-Capital- and Non-Venture-Capital-Financed Firms

Manju Puri and Rebecca Zarutskie

NBER Working Paper No. 14250

August 2008

JEL No. G24,G32

\begin{abstract}
$\underline{\text { ABSTRACT }}$
We use a new data set that tracks U.S. firms from their birth over two decades to understand the life cycle dynamics and outcomes (both successes and failures) of $\mathrm{VC}$ - and non-VC financed firms. We first ask to what market-wide and firm-level characteristics venture capitalists respond in choosing to make their investments and how this differs for firms financed solely by non- $\mathrm{VC}$ sources of entrepreneurial capital. We then ask what are the eventual differences in outcomes for firms that receive VC financing relative to non-VC-financed firms. Our findings suggest that VCs follow public market signals similar to other investors and typically invest largely in young firms, with potential for large scale being an important criterion. The main way that $\mathrm{VC}$ financed firms differ from matched non-VC financed firms, is they demonstrate remarkably larger scale both for successful and failed firms, at every point of the firms' life cycle. They grow more rapidly, but we see little difference in profitability measures at times of exit. We further examine a number of hypotheses relating to VC-financed firms' failure. We find that $\mathrm{VC}$-financed firms' cumulative failure rates are lower than non-VC-financed firms but the story is nuanced. VC appears initially "patient" in that VC-financed firms are less likely to fail in the first five years but conditional on surviving past this point become more likely to fail relative to non-VC-financed firms. We perform a number of robustness checks and find that VC does not appear to have more stringent survival thresholds nor do VC-financed firm failures appear to be disguised as acquisitions nor do particular kinds of $\mathrm{VC}$ firms seem to be driving our results. Overall, our analysis supports the view that $\mathrm{VC}$ is "patient" capital relative to other non-VC sources of entrepreneurial capital in the early part of firms' lifecycles and that an important criterion for receiving VC investment is potential for large scale, rather than level of profitability, prior to exit.
\end{abstract}

\author{
Manju Puri \\ Fuqua School of Business \\ Duke University \\ 1 Towerview Drive, Box 90120 \\ Durham, NC 27708-0120 \\ and NBER \\ mpuri@duke.edu \\ Rebecca Zarutskie \\ Duke University \\ rebeccaz@duke.edu
}




\section{Introduction}

The venture capital (VC) industry has been growing at a very fast pace for the last twenty years. In 1980 the total amount of money newly invested by venture capitalists in the U.S. was estimated at \$610 million. By 1990 this figure had already increased to \$2.3 billion and in 1998 it reached $\$ 21.4$ billion. While the numbers increased still further during the late 1990s and 2000, in 2005 the amount invested by venture capitalists was around \$22.6 billion, slightly higher than the 1998 level of $\$ 21.4$ billion. Clearly, VC is growing as a significant source of financing for new firms, yet many questions about VC as an institution, which type of firms it finances and the life cycle dynamics of VC financed firms remain. In particular much of our understanding of VC-financed firms comes from analysis of firms that are successful and survive. We have little understanding of VC-financed firms that fail, as well as the counterfactual - the life cycle dynamics of firms that could potentially use VC but do not.

Part of the reason that research into these questions is difficult is the scarcity of data on private firms - particularly non-VC-financed firms. In this paper we use a new panel data set collected by the U.S. Census Bureau that tracks firms from their birth over more than two decades to address a number of questions related to the role of VC in new firm creation. Since our data allows us large sample identification of both firms that do and do not receive VC financing we are able to characterize and quantify differences between VC-financed and nonVC-financed firms in the early part of their life cycles - from birth to exit - and to shed light on some of the outstanding questions about the role of VC in new firm creation.

In particular, we first ask to what market-wide and firm-level characteristics venture capitalists respond in choosing to make their investments. Is VC more responsive to public market signals of investment opportunity within industries, such as IPO activity or Tobin’s Q, relative to non-VC sources of financing? In terms of firm characteristics, does VC disproportionately back firms with proven success? Or is VC looking for firms with ideas that need large initial investment and eventually achieve large scale? We then ask what are the eventual differences in outcomes for firms that receive VC financing and those that do not? How do VC-financed firms that fail compare to non-VC-financed firms that fail? Or that are acquired? Are the criteria or thresholds for exit used by investors in these two sets of firms significantly different? Is VC "patient money” or is it quick to identify and terminate failures? 
Do the answers hinge on activity by particular kinds of VC? Understanding these and related questions can help us better understand the life cycle dynamics of firms that receive VC financing and shed light on the underlying incentives of venture capitalists.

We first examine new firm creation as a function of the IPO activity in an industrial sector, as well as Tobin’s Q, a more traditional public market measure of investment opportunity. Many have argued that VC and investment banks fuelled a disproportionate number of new firms in sectors with "hot” IPO and public market opportunities, in the hope of early cashing out. Interestingly, we find that while more firms are created in sectors that experience greater IPO activity and higher Tobin's Q, the proportion of VC-financed firms created in these sectors does not change significantly during these periods of positive public market signals. Thus, it is not just VC that responds to public market cues, but entrepreneurial capital in general responds to public market signals of investment opportunities in its investment in new firms. One could view this as economy-wide signals being interpreted in much the same way by different sources of capital for start-ups, as opposed to VC driving waves of new firm creation in industries with positive public market signals of investment opportunity.

We then examine which kinds of firms receive VC over our sample period. Our results support the notion that VC invests in firms with ideas and no immediate revenues, but which require large initial investment in assets and employment. We find that firms born with no commercial revenues are disproportionately financed by VC. In fact, over 50\% of new firms in the latter part of our sample which received VC financing were started without any commercial revenues. Moreover, most of these firms received VC before they realized commercial revenues. This is true in "high-tech" industries, such as biotech and computers, and in "low-tech" industries such as retail and wholesale trade. We find that at every stage of the firm's life cycle at birth, at the time of VC financing, and beyond, on average VC-financed firms persistently tend to be an order of magnitude larger than non-VC-financed firms, as measured by employment and sales. Interestingly, we see little difference in profitability before VC-financed firms are exited via acquisition or IPO. These results suggest that the key firm characteristic on which VC focuses is scale or potential for scale, rather than profitability. Even after matching each VCfinanced firm to a non-VC-financed firm on characteristics such as age of the firm, 4-digit SIC code, geographical region, and same employment size at the time the VC-financed firms first 
receives $\mathrm{VC}$, we find that scale, rather than profitability, is the distinguishing characteristic of VC-financed firms relative to non-VC-financed firms.

These results are for surviving firms. However, it is important to examine firms that survive in conjunction with firms that do not. One possible explanation for these results is that the surviving firms might simply reflect the dynamics of VC-financed firm failure. If smaller VC-financed firms are shut down earlier relative to non-VC-financed firms, this might explain why VC-financed firms are larger in our sample.

We examine a number of hypotheses about firm failure to better understand VC behavior towards companies that do not do well. Arguably, this is one of the least understood aspects of VC behavior. Our sample allows an in depth examination of new firm failure dynamics since we observe what is the eventual outcome of all firms in our sample - either failure, acquisition or IPO - and can examine firm characteristics at the time these outcomes occur. Using our matched sample of VC-financed and non-VC-financed firms, we first ask whether the larger scale of VCfinanced firms reflects a higher failure rate for firms receiving VC. Second, we ask not only whether there is a differential probability of firm failure but whether the time to failure is different between VC- and non-VC-financed firms. Third, we ask if VC-financed firms have different thresholds for failure than non-VC-financed firms. Fourth, we ask if for VC-financed firms failure is disguised as acquisition. Last, but not least, we ask if the patterns for VCfinanced firms reflect the behavior of certain kinds of VC, such as high (low) reputed VC, or whether we see these broad patterns across the board.

In answering our first question, whether the larger scale of VC-financed firms reflects a higher failure rate for firms receiving VC, both in the larger panel and in our matched sample we find that the cumulative probability of failure is lower for VC-financed firms. The failure rate for VC-financed firms is significantly lower in the larger panel and slightly lower in the matched sample. We do not observe that on average VC-financed firms are more likely to fail than their non-VC-financed counterparts. Thus, it is not the case that the average differences in size between VC- and non-VC-financed firms over time is being driven by higher VC-financed firms failure rates.

In general we find that failure dynamics are somewhat nuanced, particularly when we ask whether the time to failure is different between VC- and non-VC-financed firms. Some argue that venture capitalists are impatient and push their companies hard to grow quickly, deciding 
relatively rapidly which firms have the best chance of achieving a successful exit and terminating those that do not in the interest of allocating more capital to the likely winners in their portfolios. Others argue that VCs have a more difficult time judging which firms will be successful in the early stages of investment and equally nurture and invest in all of their firms over a certain period of time. We find that failure dynamics of VC- and non-VC-financed firms are nuanced. The answer to whether VC-financed firms fail more often is a function of the time period under consideration. We find that VC is "patient" at least in the first five years after first receiving VC. In our matched sample, the probability of a VC-financed firm failing is much lower than a nonVC-financed firm, but the probability of a VC-financed firm failing is actually higher than for non-VC-financed firms conditional on their having survived for more than five years. Thus, venture capitalists allow firms time to grow and appear to be "patient” but only to a certain point. There is a window in which they allow firms to continue and grow, but once this is crossed, then venture capitalists are relatively quick to shut their firms down.

The third question we ask with regards to failure is if VC-financed firms have different thresholds for failure than non-VC-financed firms. When VC-financed firms are ultimately shut down do they look significantly different in terms of size or profitability relative to non-VCfinanced firms that are shut down? Some argue that venture capitalists may terminate firms that other investors would keep alive because of higher VC hurdle rates, while other argue that venture capitalists give even their failed firms more opportunities to grow and prove themselves relative to investors in non-VC-financed firms in an attempt to learn which of their investments will be the huge successes. We find that in our matched sample VC-financed firms are significantly larger when they fail in terms of employees and sales, but are not very different in terms of profitability at the time of failure. In fact VC-financed firms appear slightly less profitable at failure. These results suggest that venture capitalists care about scale for all firms that they invest in, investing heavily in all their firms for an initial period until they have a better sense of which ones will be the successes in their portfolios.

Fourth, we ask if for VC-financed firms failure is disguised as acquisition. While we have observed that VC-financed firms have lower average probabilities of failure, it is possible that venture capitalists are able to sell their poor performers to other companies due to VC connections or natural synergies with potential acquirers, whereas non-VC-financed firms simply must shut down. We examine if VC-financed firms differ significantly from non-VC-financed 
firms at the time that they are acquired. We find there is no significant difference in terms of size, as measured by employment or sales, or profitability at the time of acquisition. Hence there is no evidence to suggest that VC failures are being camouflaged as acquisitions. In fact, if anything, our evidence suggests that in fact VC-financed and non-VC-financed firms must meet the same size and profitability criteria to be acquired. We also examine VC- and non-VCfinanced firms at the time they go public and find similar results. There are no significant differences between them when they go public. This analysis suggests that the large initial investments in employment and other assets by $\mathrm{VC}$ in the firms it finances is an attempt to get each firm to the critical scale and position in which it needs to be in order to be successfully exited via IPO or acquisition. More VC-financed firms achieve these successful exits with VC providing the cash and patience to grow them initially, but those VC-financed that do not achieve IPO or acquisition exits are much more likely to be shut down relative to non-VC-financed firms that manage to survive past the initial VC trial period.

Last, but not least, we ask if the patterns for VC-financed firms reflect the behavior of certain kinds of VC, such as high (low) reputed VC, or whether we see these broad patterns across the board. We find the pattern of failure that we observe in the overall sample is also observed in the subsamples of both high and low reputation venture capitalists. While there are some small differences in the exact nature of timing, the overall patterns are quite similar for both types of VC. Both high and low reputed VC-financed firms are less likely to shut down initially than non-VC financed firms, but after a point (4-5 years) the VC financed firms are more likely to shut down. Moreover, the general differences observed between VC- and nonVC-financed firms in terms of size and profitability over the life cycle and at exit are present in our both our subsamples of high and low reputed VC-financed firms.

Our work adds to the existing literature on the role that VC plays in the firms it finances. To date, this literature has mainly focused on differences between VC- and non-VC-financed firms that have had successful outcomes, such as an IPO, or on VC-financed firms in isolation (e.g., Gompers and Lerner (2001), Lerner (1995), Kaplan and Stromberg (2003, 2004)). Studies examining differences in behavior and outcomes between VC- and non-VC-financed firms have largely had to rely on firms that have gone public (e.g., Baker and Gompers (1999), Brav and Gompers (1997), Hochberg (2005), Megginson and Weiss (1991)) or firms that have had some other successful conditional outcome like joining a strategic alliance (e.g., Lindsey (2008)). A 
few studies have examined smaller hand-collected samples of private non-VC-financed and VCfinanced firms but have been limited to certain geographies, time periods and industries (e.g., Baron, Hannan and Burton (1999) and Hellmann and Puri (2000, 2002)). Another approach taken by some studies is to examine the impact of different kinds of VCs on investment outcome (e.g., Botazzi, Hellmann and Da Rin (2007), Gompers (1996), Sorensen (2007), Zarutskie (2008)). By examining the universe of private firms as captured in the Census, and comparing the life-cycle dynamics of both VC- as compared to non-VC firms, we are able to understand exit, in particular failure dynamics of VC versus non-VC financed firms. This is arguably the least understood part of the VC investing process, that throws light on VC incentives at different parts of the process.

Our analysis also informs the debate over whether venture capitalists behave in a shorttermist manner relative to non-VC sources of entrepreneurial capital in their growth and shut down decisions. Overall, our analysis indicates that VC is a relatively patient source of capital. However, there is a limit to its patience. Getting VC significantly increases firms' chances of survival in their early years and speeds their investment and growth, as venture capitalists invest in learning about which of their firms will achieve the scale and other criteria necessary for a successful exit. VC-financed firms experience high investment in employment and low profitability relative to non-VC-financed firms in the early part of their life cycles as they grow their sales and develop their business models. However, this initial nurturing period of VC financing comes with a cost. Once the period has finished VC-financed firms face a higher probability of being shut down, as well as being acquired or going public, relative to non-VCfinanced firms that also survive past the same initial trial period. While taking VC financing ex ante lowers the probability of firm failure, conditional on surviving for a number of years, the probability of failure as a VC-financed firms is actually higher.

The rest of the paper is structured as follows. Section II describes our data. Section III examines the market-level and firm-level characteristics to which venture capitalists respond when making investments. Section IV examines the differences in exit dynamics of VC- and non-VC-financed firms and explores a number of hypotheses related to the failure dynamics of VC-financed firms. Section V concludes. 


\section{Data}

We begin by describing the Longitudinal Business Database, the main panel data set we use to track firms from birth to first exit via IPO, acquisition or shut down. We also describe the U.S. Census Bureau data sets we merge to the Longitudinal Business Database to obtain additional information on firm-level sales and costs. We then discuss how we identify VCfinanced firms in the data by linking the Longitudinal Business Database to VentureXpert, a commonly used commercial data set that contains information on U.S. VC deals. Finally, we discuss how we form a matched sample of VC- and non-VC-financed firms based on firm characteristics at the time the VC-financed firms first receive VC financing. We use both the entire Longitudinal Business Database and our matched sample in our empirical analysis.

\section{A. The Longitudinal Business Database}

The Longitudinal Business Database (LBD) is a panel data set that tracks all U.S. employer business establishments from 1975 to the present. ${ }^{1}$ The version of the LBD we use ends in 2001. The LBD contains information on employment, payroll, industry, location, and organizational form for each business establishment. We can also observe the years an establishment enters and exits the LBD. Since we are interested in understanding the relation between firm-level characteristics and VC financing, we aggregate business-establishment-level payroll and employment data for multi-establishment firms using firm-level identifiers. We classify the industry and geography of multi-establishment firms as the modal industry and geography of the firms' business establishments. For a more detailed description of the variables contained in the LBD and how it is formed see Jarmin and Miranda (2002).

We begin tracking firms from their birth, or year of first entry into the LBD. A business establishment enters the LBD when it has at least one employee who is paid a wage on which U.S. payroll taxes are levied. Hence, we observe firms from the point in time at which their first business establishement hires its first tax-paying employee. ${ }^{2}$ We classify a firm's year of birth in

\footnotetext{
${ }^{1}$ The LBD is a business-establishment-level data set. A business establishment is part of a firm defined by having a particular geographic location. For example, a law firm with an office in Boston and an office in New York would have two business establishments. Likewise, a manufacturing firm with three different plants operating in different locations, two in Illinois and one in Wisconsin, would have three business establishments.

${ }^{2}$ Firm owners who also work for their firms typically pay themselves a wage. Hence, firms whose only employees are their owners will still typically be included in the LBD.
} 
the LBD as the year in which its first establishment enters the LBD. Most firms, including VCfinanced firms, enter the LBD as single establishment firms. We track firms from their year of birth to the year of their first exit event - IPO, acquisition or shut down - or until 2001 when our data ends.

We classify a firm as shutting down, or failing, when all of its establishments exit the LBD. A firm which has two or more business establishments will only be classified as failing if both of its establishments exit the LBD. The year of failure for the firm will be year in which the last establishment is shut down. We classify a firm as having been acquired if all of its business establishments have been acquired by another firm. We are able to distinguish between a firm acquiring another firm's establishments and having its own establishments acquired by another firm since the LBD allows us to observe which firm takes control of the business establishments. We categorize an acquisition exit event as the latter scenario in which a firm's establishments are taken over by another firm. Finally, we identify firms that have had an initial public offering of the firms' equity by merging a list of firms having IPOs between 1975 and 2001 in the U.S. to the LBD based on firm name.

If a firm has more than one exit event, e.g. if it goes public then gets acquired, we classify the firm's exit event as the one which occurs first. We track firms from their birth to their first exit event because we are interested in comparing outcomes of firms during years in which venture capitalists are actively involved in the companies they finance. Most venture capitalists sell their holdings in their portfolio companies at the first exit opportunity.

\section{B. Obtaining Information on Sales and Costs}

We supplement the payroll and employment data in the LBD with sales data from three additional Census data sources - the Economic Censuses of Services, Retail and Wholesale Trade, the Longitudinal Research Database for Manufacturing and the Standard Statistical Establishment List. We also obtain additional cost information from the Longintudinal Research Database.

The Economic Censuses of Services, Retail Trade and Wholesale Trade collect information on the value of goods produced in each of business establishment in the services, 
retail and wholesale trade industries every five years, for years ending in 2 and $7 .^{3}$ Although the variable is labeled as sales in the Economic Census Waves it is not necessarily identical to cash revenues reported on a firm's financial statement or tax return. The sales number in the Economic Census waves is an estimate of the value of goods produced by the establishment. As a result, very few business establishments report zero sales in the Economic Census waves since they all typically produce something whether or not it is actually ever sold for cash. Thus, when cash revenues are zero, the Economic Census sales value may be positive but very low. The correlation between Economic Census sales and tax return revenues which we obtain from the Standard Statistical Establishment LIst in 1997 and the 1997 Census waves is very high at around 0.9, and the average absolute difference between these two variables is very low at around a few hundred dollars.

For firms in the manufacturing industries (SIC codes 2000-3999), we are able to obtain information on both the value of goods produced as well as information on operating costs and capital expenditures. In addition to collecting this data in the five-year Economic Census of Manufactures waves, the Census Bureau also collects this information for a stratified random sample of manufacturing firms every year as part of its Annual Survey of Manufactures. The Economic Census of Manufactures waves combined with the Annual Survey of Manufactures in the non-Census years comprise the Longitudinal Research Database (LRD).

The SSEL is list of business establishments maintained by the U.S. Census Bureau that is updated on an annual basis. The SSEL contains data from U.S. government administrative records, such as tax returns, and is augmented with data from Census surveys and data sets. Much of the information contained in the LBD is derived from information in the SSEL. Beginning in 1995, the SSEL contains firm-level revenues as reported on firms' tax returns. Tax return revenue data is available for about two thirds of firms in the SSEL. The advantage of the SSEL tax return data is that it gives a measure of actual cash obtained by each firm in a given year, as opposed to an estimate of the value of goods produced as in the other Census data sets described below. The disadvantage, however is that the data is only available in the last seven years of our twenty year sample period. Thus, we primarily use the sales data in the Economic Census waves and the LRD in our empirical analysis.

\footnotetext{
${ }^{3}$ The service industries are those with SIC codes 7000-8999. The retail and wholesale trade industries are those with SIC codes 5000-5999.
} 


\section{Identifying VC-financed Firms in the $L B D$}

We identify firms in the LBD as VC-financed if they can be matched to a June 2005 extract of VentureXpert based on name and address. VentureXpert is a database maintained by Thomson Financial which contains information on both venture capital investment firms and the companies in which they invest. Among other variables, VentureXpert contains information on which firms receive VC financing, from which VC firms and funds, and when the investments take place. Comprehensive coverage of the U.S. VC industry by VentureXpert begins in the early 1980s. We include in our extract any VC-financed firm located in the U.S. and whose first round of financing is classified as either "Startup/Seed," "Early Stage," "Expansion," and "Later Stage." We exclude companies whose first round of financing is recorded as "Buyout/Acquisition," "Other," and "Unknown." We also exclude companies that are missing name or address information. We match 16,109 of these VentureXpert companies to the LBD. Appendix A contains a detailed description the algorithm we use to match VentureXpert to the LBD.

\section{Matching VC-Financed and Non-VC-Financed Firms in the LBD}

We also form a one-to-one matched sample of VC- and non-VC-financed firms in the LBD based on firm characteristics at the time VC-financed firms first receive VC. One may always ask whether differences between VC- and non-VC-financed firms are due to venture capitalists selecting better firms or entrepreneurs or whether the nature of VC financing itself and the role venture capitalists may play in the governance and operation of VC-financed firms cause these observed differences between VC- and non-VC-financed firms. Hence our next step is to match each VC-financed firm to a non-VC-financed firm at the time of getting VC funding based on four characteristics. These characteristics are age of the firm, 4-digit SIC code, geographical region, same employment size. ${ }^{4}$ We re-examine the relation between VC financing and firm size and exit for a set of firms that are observationally similar at the time at which one of them gets VC funding and the other does not. While this does not completely enable us to distinguish selection from causation, it does allow us to make a statement about differences between VC-

\footnotetext{
${ }^{4}$ We do not match on sales because we only observe this variable in five year intervals over our sample period for most industries.
} 
and non-VC-financed firms that are identical on certain observable characteristics at the time of VC financing. Appendix B contains a detailed description of the matching process as well as summary statistics for the matched sample. The final matched sample contains 7,632 VCfinanced and 7,632 non-VC-financed firms which enter the LBD between 1981 and 2001.

\section{Which Firms Receive VC Financing?}

How quantitatively important is VC in new firm creation in our data? We see that a statement on the quantitative importance of VC in new firm creation depends critically on the measure used. From the point of view of new firm foundings, VC is close to irrelevant. VCfinanced firms are an extremely small percentage of all new firms created in the LBD averaging $0.1 \%$ over the 20 year sample period 1981 to 2001 and increasing to $0.2 \%$ in the late 1990s. If instead of focusing on the number of firms that get VC backing, we focus on other measures we get a different picture of the importance of VC in new firm creation and in the economy as a whole. Consider the amount of employment generated by VC backed firms. When we measure the amount of employment generated by VC backed firms we find that it accounts for nearly $10 \%$ of employment in the US in the late 1990s and early 2000 s, steadily rising from about $5 \%$ in the 1980 s.

Thus, casual empiricism suggests that VC finances firms that will rapidly grow and that will eventually become large players in certain industries. What is different about firms that receive VC financing compared to those that do not? How do venture capitalists identify their investments and what do these firms look like when they first get VC? While we have some sense that VC-financed firms are concentrated in certain "high-tech" industries from surveys such as Moneytree and aggregate statistics reported by the National Venture Capital Association, it is unclear how the industry composition of newly created firms that receive VC financing compares to the industry composition of newly created firms that do not receive VC financing. Moreover, little is known on how the size and profitability of VC-financed firms compares to that of non-VC-financed at birth, and the time of VC financing, and prior to exit. Thus, we begin our analysis by asking to what market-wide and firm-level characteristics venture capitalists respond in choosing to make their investments and how this differs for firms financed solely by non-VC sources of entrepreneurial capital. 


\section{A. VC Financing by Industry}

We start by asking what industries VC backs relative to other sources of entrepreneurial capital over our 20 year sample period. Table I presents industry counts for all VC- and nonVC-financed firms that enter the LBD created between 1981 and 2001. ${ }^{5}$ Industry counts are reported for all firms born between 1981 and 2001 (first panel), for firms that are born between 1995 and 2001 (second panel), and for firms that are born between 1995 and 2001 and have zero cash tax revenues as reported in the SSEL in their first year in the LBD (third panel).

We classify firms into nine industry categories that correspond to the industry categories used by VentureXpert to describe VC-financed firms in its database. We map 4-digit SIC codes to these categories by noting the SIC codes assigned by the LBD to VC-financed firms in VentureXpert. If a firm's SIC code does not fall into one of the first eight industry categories it is classified as "Other"; thus, all firms in the LBD are categorized and counted in Table I.

Focusing on the first panel in Table I, we observe that the vast majority of newly created firms are not VC-financed. The overall proportion of newly created firms that are VC-financed across industries is very small - 12,865 VC-financed firms versus 12,196,412 non-VC-financed firms, or less than $0.2 \%$ over our entire sample period. However, if we observe the breakdown by industry category we note that in some industries the proportion of VC-financed firms being created is much higher. In particular, the percentage of VC-financed firms created in the "Computer", "Electronics" and "Telecom" industries is well above 1\%, between 10 and 15 times greater than the population average. ${ }^{6}$ This breakdown is consistent with the notion that VC disproportionately backs firms in "high-tech" industries.

However, Table I also demonstrates that VC finances a large number of new firms in "low tech" industries as well, although as a much smaller percentage of the total number of new firms in these industries. Over the 1981-2001 period VC financed 8,055 new firms in the "high

\footnotetext{
${ }^{5}$ We start our sample period in 1981, rather than 1975, the first LBD year, since the number of VC-financed firms that enter the LBD prior to 1981 is much smaller than in later years. VC investing activity did not become prevalent until 1980 after the revocation of ERISA's prudent man rule, and VentureXpert's coverage of the VC industry increases starting in the early 1980s. VC-financed firms are firms that receive VC at any point during their lives, either at birth or in any subsequent year. The majority of VC-financed firms, over 80 percent, receive VC financing within their first three years.
} 
tech” industries of “Computer”, "Biotech/Medical”, "Electronics” and “Telecom” and 5,810 firms in the "low tech" industries of “Consumer”, "Finance”, "Business”, "Industrial” and “Other”. This raises the question of whether VC is looking for similar characteristics in firms it finances in "high tech" versus "low tech" industries. The second and third panels of Table I are able to shed light on one dimension of this question. The second panel of Table I reports industry counts for VC- and non-VC-financed firms created between 1995 and 2001. The third panel reports industry counts for firms created during this time that have zero cash revenues as reported on their tax returns. This data is taken from the SSEL as described in Section II.B. 47\% of VC-financed firms created between 1995 and 2001 had zero cash revenues in their first year versus $6.7 \%$ of non-VC-financed firms. We obtain these percentages by dividing the number of firms with zero tax return revenues in their first year by the number of firms with nonmissing tax return revenues, i.e. $(2,615 / 5,559)$ in the first case and $(195,677 / 2,928,035)$ in the second case.

VC disproportionately finances firms that are created without having any commercial revenues. When we compute the percentage of new VC-financed firms that have zero commercial revenues in their first year by industry, we notice that even in the "low tech" industries, the percentage of new VC-financed firms that have zero commercial revenues in their first year remains high, at between 30 and 40\% of firms. The percentage of "high tech" new VCfinanced with zero commercial revenues in their first year is slightly higher at between $40 \%$ and $55 \%$.

Table I suggests that a large percentage of the firms venture capitalists back develop new products without any initial sales prospects, even in "low tech" industries. ${ }^{7}$ Thus, the kinds of firms VC finances share an important similar characteristic across industries along this dimension. We will later explore whether these sorts of firms that VC disproportionately finances have as a result higher growth and failure rates.

\section{B. VC Financing and Public Market Signals}

\footnotetext{
${ }^{6}$ In addition, if doctor's offices are excluded from the "Biotech/Medical” industry category, the percentage of VCfinanced firms also rises to greater than $1 \%$.

${ }^{7}$ This finding is consistent with prior work by Kortum and Lerner (2000) who assess the contribution of VC to innovation in the U.S. and find that it is positively related.
} 
Many have argued that VC and investment banks fuelled a disproportionate number of new firms in sectors with "hot" IPO and public equity market opportunities, in the hope of early cashing out. To examine this question, we regress the natural logarithm of new firms created in each of the 189 industry-years in our 21-year sample period of 1981 to 2001 of the LBD on the natural log of each of three public equity market signals in each industry lagged by one year. In each OLS regression we include year and industry fixed effects and cluster standard errors by industry-year. Our three public market signal measures are the natural log of IPOs in each industry-year, the weighted average of Tobin's $Q$ in each of the industry-years, and total equity market capitalization in each of the industry-years.

The first three columns in Panel A of Table II report the estimated coefficients and tstatistics for OLS regressions of log new firms created in an industry-year on the three lagged public market signal variables. The first three columns of Table II Panel B report OLS coefficients and t-statistics for regressions of the log of new firm employment in an industry-year on the three public market signal variables. In each OLS regression we include year and industry fixed effects and cluster standard errors by industry-year. In each specification the public market signal variable positively and significantly predicts new firm creation, both equal and employment-weighted, in an industry-year. To give a sense of the economic magnitudes of the regressions, measuring from sample means a one standard deviation in each of the public market signal variables leads to an increase in the number of new firms created in an industry-year by between one thousand, in the case of IPOs, and three thousand, in the case of Tobin's Q and market capitalization signals.

These regressions tell us that new firm creation and employment responds to public equity market signals of investment opportunity. But is VC disproportionately fueling this response? To examine this question, we estimate regressions of the log odds ratio of VC-financed to nonVC-financed new firms (both equal- and employment-weighted) created in each of the 189 industry-years as a function of the three lagged public market signal variables. The last three columns of Panels A and B in Table II report the estimated OLS coefficients and t-statistics. We see that the log odds ratio of VC- to non-VC-financed new firms does not significantly change in response to Tobin's Q or total market capitalization within industry-years. There is a positive marginally significant response to IPO activity when considering equal-weighted new firm creation in an industry, but the economic magnitude is small. For a one standard deviation in the 
IPO signal variable, the percentage of new firms created in response that are VC-financed rises by 0.02 percentage points at the sample mean. Thus, even when using IPOs as the signal of investment opportunity, the most profitable exit option for VC, the percentage of newly created firms that are VC-financed remains fairly stable in response to public equity market signals of investment opportunity.

VCs do not appear to be disproportionately financing new firm creation and employment in response to public equity market signals of investment opportunity. ${ }^{8}$ The results presented here do not support the popular view that VCs are the primary drivers of new firm creation in sectors where large IPO activity occurs. Rather our results suggest both entrepreneurs and venture capitalists respond to public market signals of investment opportunity in a similar fashion. However, as we will see in Section IV, VC appears to be better able to invest in new firms that grow to a state critical for an exit in the public markets relative to non-VC sources of new firm capital.

\section{VC Financing and Firm Size}

We have seen that VC tends to focus on high-tech industries, and firms born without any commercial sales in all industries. Does VC appear to have scale, actual or potential, criteria for the firms in which it invests? Is it the case that VC-financed firms grow larger relative to nonVC-financed firms on average? If so, for what measures of size is this true, e.g., employment, sales, or profitability? And at what age is this true?

\section{C.1. Comparing All VC- and non-VC-financed Firms}

Figures 1a and 1b depict the average employment and sales by firm age for all VC- and non-VC-financed firms in the LBD born between 1981 and 2001. The sales variable depicted in Figure $1 \mathrm{~b}$ is the sales variable from the Economic Censuses of Services, Wholesale and Retail Trade and the LRD. In the remaining analysis we choose to use this measure of firm sales, rather

\footnotetext{
${ }^{8}$ In related empirical work, Gompers et al (2008) find that different kinds of VCs respond more or less strongly to public market signals of investment opportunity by increasing their total investment in their portfolio companies. While they find different responses amongst different types of VCs, we show that when we consider all types of financing available to new firms, there does not seem to be a large differential response of VC relative to other types of capital in investment via new firm creation in response to public market signals.
} 
than SSEL tax return revenues, because we can observe this measure of sales over our entire sample period.

The first fact that emerges from Figures $1 \mathrm{a}$ and $1 \mathrm{~b}$ is that VC-financed firms are larger than non-VC-financed firms, measured by both employment and sales, at each age of the lifecycle prior to first exit. Second, the size difference between VC- and non-VC-financed firms becomes larger with firm age, i.e. the average growth rate of VC-financed firms is larger. Figures 1a and 1b suggest that actual or potential scale of investment in employment and sales is an important criterion in how venture capitalists choose which firms to finance. VCs invest in companies that grow faster both in terms of employment and sales relative relative to non-VC-financed firms. Once VC-financed firms reach a certain size, they exit, leaving smaller VC-financed firms behind. Non-VC-financed firms, on the other hand, remain relatively small on average, only growing gradually over the lifecycle.

\section{C.2. Comparing Matched VC- and non-VC-financed Firms}

Figures 2a and 2b plot average firm employment and sales in "match time”, or years relative to matching for the sample of matched VC-financed and non-VC-financed firms. Recall that each non-VC-financed firm is matched to a VC-financed firm in the year the VC-financed firm first receives VC. We see that prior to VC financing, VC-financed and non-VC-financed firms have similar employment and sales levels. By construction of the matching process their employment levels are very similar at time zero, the point of matching. For firms that are matched at ages greater than one, and whose averages make up the negative match time portion of Figures $2 \mathrm{a}$ and $2 \mathrm{~b}$, we see that in fact the non-VC-financed firms have slightly larger employment and sales levels prior to matching. VC-financed firms grow slightly faster than non-VC-financed firms in terms of employment prior to receiving VC financing. This suggests that VCs are looking for evidence of prior growth in the firms they back, at least in terms of employment, though the growth is small with an increase in about 4 employees in the years prior to receiving $\mathrm{VC}$ financing.

After VC financing, we see very rapid growth in the employment of VC-financed firms relative to non-VC-financed firms. While VC-financed and non-VC-financed firms are matched at an average of 20 employees each, five years later VC-financed firms have on average just under 70 employees, while non-VC-financed firms have grown to only grown to just under 30 
employees. Beyond five years after matching, or receiving VC financing in the case of VCfinanced firms, we see greater employment growth by VC-financed firms relative to non-VCfinanced firms, but the growth slows dramatically relative to the growth seen in the first five years after VC financing first occurs. In the first several years after matching, VC-financed firms and non-VC-financed firms both experience increases in sales, but sales growth is greater for VC-financed firms. As we also saw in Figure 1b, the growth rate in VC-financed firm sales slows and at some points declines later on in the lifecycle as VC-financed firms exit via acquisition, IPO and failure. Non-VC-financed firms do not "catch up" to VC-financed firms in these later years. Non-VC-financed firms also continue to grow on average, but a much slower rate than the VC-financed firms even in this later point in their lifecycles.

Figure 2c plots a measure of profitability, (Sales-Payroll)/Sales, for VC- and non-VCfinanced firms in match time. Since we only have operating costs for manufacturing firms, we use payroll as our measure of cost and track our proxy for profitability over time. We see that prior to matching VC-financed exhibit slightly lower profitability then non-VC-financed firms, 0.60 versus 0.63 on average. After matching, and after the VC-financed firms first receive VC, the difference in profitability increases dramatically. It dips to 0.51 for VC-financed firms in the first several years after receiving VC, while for non-VC-financed firms the profitability margin still hovers between 0.62 and 0.65 . This suggests that in addition to hiring more employees in the initial years after receiving VC, these employees are paid higher wages relative to the increase in sales for VC-financed firms that we observe in Figure 2b.

Figure 2c buttresses the claim that VCs invest heavily in employment, not only via larger numbers of employees but also via higher wages, in the first several years after investing in a firm. As firms age and exit, VC-financed firms' profitability comes into line with that of nonVC-financed firms, but VC-financed firms are never on average more profitable than non-VCfinanced firms. Figure 2c indicates that on average VC-backed firms are larger but no more profitable than non-VC-financed firms prior to their being exited by the venture capitalists. Moreover, it suggests that VC looks to invest in firms that invest heavily in both number of employees and wages relative to sales growth in the initial years of the investment.

We now more rigorously analyze the size differences between the matched VC- and onVC-financed firms in a regression framework. We regress our firm size and profitability measures on a dummy variable, VC, which equals one for VC-financed firms as well as two time 
variables, TimefromMatch, which measures how far a firm is in years from being matched to its ex-ante observationally equivalent counterpart, and TimefromVC, which measures how far a VC-financed firm is in years from first receiving VC financing. TimefromVC is formed by multiplying the VC dummy variable by TimefromMatch. We run OLS panel regressions on the VC dummy and time variables, as well as the squares of the time variables to capture nonlinearities in the relation between firm size and time. In each regression we also include year fixed effects, industry fixed effects, and control for the age at which firms were matched to each other.

Table III reports coefficients and t-statistics, corrected for clustering by firm, for OLS size and profitability regressions in our panel of matched VC- and non-VC-financed firms. The top panel reports estimates for the entire LBD. The bottom panel reports estimates for the LRD for manufacturing firms for which we have more detailed cost data. We focus first on the LBD estimates in the top panel. The first three specifications regress the natural log of employment and sales as well as our payroll profitability measure on just the VC dummy variable and TimefromMatch and TimefromMatch $\wedge 2$. We see that VC-financed firms are on average larger, both in terms of employment and sales, and less profitable than non-VC-financed firms while VCs are involved with these firms as evidenced by the strongly significant coefficients on the VC dummy variable. The coefficients on the TimefromMatch variable indicate that firms in our matched sample grow over time and become slightly less profitable before an exit event, though these growth rates slow given the coefficients of opposite sign on TimefromMatch^ ${ }^{9}{ }^{9}$

The last three specifications in the top panel of Table III allow us to see whether the growth pattern in employment, sales and profitability differs for VC-financed firms. We find that VC-financed firms grow more quickly in terms of both employment and sales after VCs invest in them relative to their matched non-VC-financed counterparts, as evidenced by the positive and significant coefficients on TimefromVC in the first two regressions. However, the growth rates in size for VC-financed firms also level off more rapidly in later years, perhaps as VCs exit their successful investments more rapidly, as evidenced by the negative and significant coefficients on TimefromVC^2. Finally, the profitability regression indicates that VC-financed firms are less profitable than non-VC-financed firms initially but begin to catch up, as evidenced 
by the positive and significant coefficient on TimefromVC^2 , although the magnitudes of the coefficients indicate that it would take VC-financed firms over ten years to eventually become more profitable than their non-VC-financed counterparts.

The bottom panel of Table III repeats the regression analysis on the LRD, the subsample of manufacturing firms for which we have more detailed cost information. Instead of regressing (Sales-Payroll)/Sales on our control variables, we use Return on Sales (ROS) as our dependent variable. We calculate ROS by subtracting operating costs and capital expenditures from sales and divide this number by sales. In general the regression estimates for the LRD are similar to those for the entire LBD in Table III.

The estimates in Table III show that the patterns in employment, sales and profitability between VC- and non-VC-financed we observed in Figures 2a, 2b and 2c hold in a regression framework. Prior to VC financing VC-financed firms have similar employment and sales sizes to non-VC-financed firms, but grow much more rapidly after VCs invest, especially in the first several years, before seeing a leveling off of growth. VC-financed firms are also on average less profitable than non-VC-financed firms and do not become more profitable prior to exit years after a VC first invests in them prior to exit. Thus, a key difference between VC-financed and non-VC-financed firms that emerges from our analysis is firm scale. Larger firm scale rather than higher profitability seems to be an important criterion for VC-financed firms to achieve prior to exit.

\section{VC Financing and Firm Exit}

We have seen that VC-financed firms change enormously relative to non-VC-financed firms in terms of size after venture capitalists come on board. However, it is unclear to what extent these differences emerge because all VC-financed firms grow more quickly or because venture capitalists exit smaller firms more quickly relative to non-VC investors. One characterization of venture capitalists often found in anecdotal evidence is that they encourage the development of the one or two very high growth firms in their portfolio, i.e., the potential

\footnotetext{
${ }^{9}$ Note that the reduced number of observations in the sales and profitability regressions is due to the fact that we only observe sales data in five year intervals for most industries. It is not due to many values of sales being zero. Because our sales variable measures the value of goods produced in a given year, it is rarely equal to zero.
} 
EBays and Googles, and care little about the rest of their portfolio. Some argue that venture capitalists are quick to shut down companies; others suggest that venture capital is patient money and venture capitalists recognize the option value in their investments and exert effort to ensure companies do not close down. Exit outcomes, particularly when the outcome is firm failure, is arguably one of the least understood aspects of VC behavior towards companies, worthy of further investigation.

One way to assess whether the size differences between VC- and non-VC-financed firms is being driven by differences in their exit rates is to examine the standard deviations of the size variables over time. If venture capitalists are shutting down their smaller firms sooner to push the growth of their larger firms, we should expect to see a decline in the variability of VCfinanced firm size as firms age. Table IV presents averages and standard deviations for employment, sales and our payroll profitability measure for VC- and non-VC-financed firms in the matched sample. The averages are those depicted in Figures 2a to 2c. We see that, in fact, the standard deviations of employment and sales increase for VC-financed firms, especially in the first five years after receiving VC financing, and the standard deviations of non-VC-financed firms actually decrease. However, after five years, both the growth and standard deviations of VC-financed firms level off, while non-VC-financed firms continue on a relatively more stable path. This suggests that, at least initially, venture capitalists do not exit their smaller firms in the interest of growing their more successful firms.

\section{A. Cumulative Exit Rates}

We analyze more directly whether VC-financed firms have different exit rates than nonVC-financed firms, both in terms of successful exits, IPOs and acquisitions, and failures. We examine the cumulative exit rates in both the entire LBD and in our matched sample of VC- and non-VC financed firms.

Table V presents cumulative exit rates for all VC- and non-VC-financed firms that enter the LBD between 1981 and 2001. We calculate the total percentage of firms in a particular cohort that have exited the LBD, via failure, acquisition or IPO, after a particular number of years. For example, $17.6 \%$ of non-VC-financed firms fail after one year and $31.7 \%$ fail after one or two years. Thus, the percentage of non-VC-financed firms that failed after two years, but not after one year was 31.7 minus 17.6 or $14.1 \%$. A main fact that emerges from Table V is that 
there are enormous differences in the failure rates between VC- and non-VC-financed firms. The cumulative failure rate of non-VC-financed firms by the end of year five is 51\%, and for VC-financed firms it is only 19\%. After year five, the difference in the marginal failure rate between VC-financed and non-VC-financed firms declines dramatically; for each successive year the probability of exiting, conditional on surviving to age five is about the same for both VC- and non-VC-financed firms and continues to decline as firms age. This suggests that VCs make the biggest difference in the early years of firms' lifecycles or at least select firms that are much less likely to fail early on.

Turning to the cumulative acquisition and IPO exit rates for all firms in the LBD in Table $\mathrm{V}$, we see that VC-financed are much more likely to be acquired and go public relative to nonVC-financed firms. The biggest differences emerge in the first six or seven years of a firm's life and then lessen over time. The cumulative acquisition and IPO exit rates for non-VC-financed firms grows more steadily over time. This suggests that VCs actively promote or select their companies to exit via these two most profitable exit routes earlier, by perhaps growing them more rapidly earlier on in the lifecycle.

In Table VI we report the cumulative exit rates of firms in our matched sample. We see that VC-financed firms are once again less likely to fail and more likely to be acquired and to go public than non-VC-financed firms. Five years after matching, about 22\% of non-VC-financed firms have failed, whereas about $30 \%$ of non-VC-financed firms have failed. $3.6 \%$ of VCfinanced firms have been acquired and $8 \%$ have gone public. Only 1.3\% of non-VC-financed firms have been acquired, and the percentage going public is too small to disclose. Thus, slightly more VC-financed firms have exited the matched sample at five years, though fewer have done so by failing. Ten years after matching, an additional 5\% of both VC- and non-VC-financed firms have failed. However, since more VC-financed firms have exited via IPO and acquisition, the marginal probability of failure, conditional on not exiting in years 6 to 10 is actually higher for VC-financed firms. Due to much greater failure rates of non-VC-financed firms in the first five years after matching, the cumulative failure rate between VC- is still significantly less than non-VC-financed firms ten years after matching. ${ }^{10}$

\footnotetext{
${ }^{10}$ Total cumulative failure rate for both VC- and non-VC-financed firms is relatively low after 10 years is due to right censoring in the data. More of the observations come from latter part of our sample. If we examine only firms that enter the LBD between 1981 and 1987, 50\% of VC-financed firms have failed after 10 years compared to 56\% of non-VC-financed firms.
} 
Tables V and VI demonstrate that VC financing is strongly associated with a lower cumulative probability of firm failure. Thus, the larger VC-financed firm sizes relative to nonVC-financed firms we observed in Section III.C are not being driven by higher failure rates of VC-financed firms relative to non-VC-financed firms. Rather, VC-financed firms on average dominate non-VC-financed firms both in terms of having higher growth rates and lower failure rates even in our matched sample.

We next examine a number of more nuanced hypotheses relating to VC-financed firm failure.

\section{B. Timing of Exit Outcomes}

We have seen that even in our matched sample of firms, VC-financed firms are less likely to fail, cumulatively, than non-VC-financed firms. However, it appears the story is a bit more nuanced. In our matched sample, after five years the failure rate of VC-financed firms increases relative to that of surviving non-VC-financed firms. We first ask whether the time to failure is significantly different for VC- and non-VC backed firms. Is VC patient money or are they quick to shut down so that they can focus on the "stars" of their portfolio? In this section we examine the timing of firm failures in our matched sample of VC- and non-VC-financed firms.

Since each firm in our sample can experience only one exit event, we model firm exit in a multinomial logit model in which the excluded outcome is no exit. We report estimated coefficients, z statistics corrected for clustering by firm in parentheses, followed by marginal probabilities calculated at sample means in brackets, for two multinomial logit specifications in Table VII. In the first specification we model firm exit as a function of a VC dummy, time from matching, as well as age at which firms were matched and industry and year fixed effects. In the second specification, we also control for time from first receiving VC financing for the set of VC-financed firms to be able to distinguish differences in the dynamics of firm exit between VCand non-VC-financed firms.

The exit patterns we observed in Table VI are born out in the multinomial logit models. Focusing on the first model, we see that VC-financed firms are much more likely to be acquired and to go public and are less likely to fail than non-VC-financed firms. On average, VCfinanced firms are 0.7 percentage points more like to be acquired, 1.4 percentage points more likely to go public and 1.2 percentages less likely to fail in a given year. 
In the second model, we see that when we control for differences in the exit dynamics between VC- and non-VC-financed firms the marginal probability of being acquired increases by 0.1 percentage points for each year that a firm has VC-financing, from a base starting point advantage of 0.3 percentage points, relative to non-VC-financed firms. Likewise, the marginal probability of going public increases by 0.2 percentage points for each year a firm has VC financing, from a base starting advantage of 0.5 percentage points, relative to non-VC-financed firms. However, when it comes to failure, the story is more nuanced. After initially receiving VC financing, VC-financed are less likely to fail by 6.8 percentage points in the first year. However, for each year that the VC-financed firm ages, its marginal probability of failure increases by 1.7 percentage minus 0.1 percentage point times the square of the number of years after VC financing. Up until five years after receiving VC financing, the probability of failing is lower for Thus, at five years after first receiving VC financing, the marginal probability becomes greater relative to non-VC-financed firms. In each additional year, the marginal probability of failure increases for VC-financed firms relative to non-VC-financed firms.

The estimates in Table VII provide robust evidence that VC is "patient" money in the early part of firms' lifecycles. In the first five years after receiving VC, VC-financed firms are given a chance to grow while venture capitalists rapidly grow the firms in terms of employment and sales relative to non-VC-financed firms. However, after this initial growth period, VCfinanced firms have a higher mortality rate, as well as exit rate via acquisition and IPO, relative to non-VC-financed firms. While VC is initially patient (i.e., for about five years), its patience fades in the later years of the investment, perhaps after the venture capitalists have had a chance to observe whether their initial investments will bear fruit. This nuanced finding on the relative failure dynamics of VC- and non-VC-financed firms is consistent with the results we saw on firm size and profitability in Section III.C. Venture capitalists invest heavily in firm employment and payroll in the first five years after investing. This is the period over which we see the most rapid growth in VC-financed firms relative to non-VC-financed firms. After five years, when VC-financed firms failure rates as well as acquisition and IPO rates are higher relative to nonVC-financed firms, the growth of VC-financed firms slows relative to surviving non-VCfinanced firms, which continue to grow steadily and slowly.

Before moving to our next hypothesis on VC-financed firm failure, we perform a robustness check to the multinomial logit analysis in Table VII. VentureXpert classifies about 
30 percent of the VC-financed firms in the LBD that fail in the LBD according to our definitions as having been acquired. These firms exit the LBD which means they cease to operate in any of their old locations; however VentureXpert lists these firms as having been acquired. It is likely that just the assets of these VC-financed firms are acquired rather than the employees of these firms becoming part of an existing firm, which explains why the firms' business establishments disappear from the LBD. In the analysis in Table VIII, we choose to classify these firms as failures, because even if the assets are being sold to another firm, the VC-financed firms ceases to operate in its old form. However, as a robustness check we re-classify these VC-financed firms as acquisitions instead of failures and re-estimate our multinomial logits. We find that VCfinanced firms are still less likely to fail than non-VC-financed firms five years after receiving VC financing and are more likely to fail six years and later after VC financing.

\section{Do VCs Have Different Thresholds for Failure?}

VC-financed firms are initially more likely to survive, but then have higher shut down rates relative to non-VC-financed firms over time. A related question is whether the threshold for firm survival is more stringent for VC-financed firms. Do venture capitalists simply wait to see if there is option value to be realized but then when they do shut down firms, have a more stringent criterion for what it means to be a successful surviving firm relative to investors in non-VCfinanced firms?

We next examine whether VC-financed firms look different than non-VC-financed firms at failure. We report average employment, sales and profitability of firms in the year they fail in the top panel of Table VIII. The first row in the top panel reports these numbers for the entire LBD. The second row reports averages for only the manufacturing firms in the LRD.

We see that VC-financed firms are on average larger than non-VC-financed firms when they fail, both in terms of employment and sales. However, they are not any more profitable. In fact, using the payroll profitability measure in the larger sample of LBD firms, we see that VCfinanced firms are marginally less profitable than non-VC-financed firms at failure. Thus, VCs do not appear to have higher survival thresholds in terms of profitability relative to investors in non-VC-financed firms. Rather, consistent with the size and profitability results we reported earlier, VCs seem to grow all of their portfolio companies to a certain minimum level before deciding to shut down them down. This shut down decision does not seem to be based on 
observable profitability but rather on scale, or perhaps some other unobservable variable. The results in Table VIII suggest that rather than having more stringent requirements for shutdown in terms of size or profitability, it seems that VC-financed firms have been allowed to grow more and receive more investment before ultimately shutting down relative to non-VC-financed firms.

\section{Are VC-financed Firm Failures Disguised as Acquisitions?}

An alternate explanation for our results is that the lower failure rates for VC-financed firms reflects the fact that some failures are disguised as acquisitions or IPOs. However, it may also be the case that both VC- and non-VC-financed firms have to meet minimum eligibility criteria before other corporations or public investors will buy their equity. To shed light on these alternative hypotheses, we compare average size and profitability of VC- and non-VC-financed firms at acquisition and IPO in the last two panels of Table VIII.

There is no significant difference in the size and profitability of VC- and non-VCfinanced firms at acquisition or IPO. This finding is also robust to the alternative definition of VC-financed firm acquisition explored in Section IV.A. Thus, it does not appear that venture capitalists are disguising failures as acquisitions and that the lower overall failure rates for VCfinanced firms truly reflects a difference in failure rates between VC-financed and non-VCfinanced firms. Moreover, it seems that VC-financed firms are not on average able to take firms public or sell them to other firms without meeting size and profitability standards that non-VCfinanced firms must also meet.

\section{E. Are Exit Patterns of VC-financed Firms Driven by Certain Kinds of VCs?}

Another possible explanation for our results is that the relation between VC financing, failures, firm size and profitability and overall firm exit dynamics is driven by certain kinds of VC, say high (low) reputed VC. A literature has developed that explores the impact of different types of VCs on investment outcomes (e.g., Botazzi, Hellmann and da Rin (2007), Gompers (1996), Sorensen (2007) and Zarutskie (2008)) independent of the prior literature which documents that venture capitalists behave in ways consistent with principal-agent theories when dealing with their portfolio companies (e.g., Lerner (1995) and Kaplan and Stromberg (2004, 2003). Hence understanding whether the relation between VC financing, firm scale and exits (both successes and failures) differ significantly for high and low reputed VCs is an interesting question in its own right. 
We create a measure for "high reputation" VC firms as those that are in the top quartile of the age distribution of VC firms in VentureXpert. There is evidence that older VCs and those that have more experience doing deals generally have higher returns. We thus use age as our measure of the reputation of a VC firm's quality to its investors. ${ }^{11}$

For each VC-financed firm in the LBD, we calculate the maximum age of the VC firms investing in the companies in their first round of VC financing. If the oldest VC firm which invests in the company's first round is in the upper quartile of the VC firm age distribution, at the time it invests in the company, then the VC-financed firm is labeled as having a high reputation VC firm as an investor. A dummy variable, HighRepVC, is set equal one for these VC-financed firms and set equal to zero for all other VC-financed firms.

We re-estimate our firm size, profitability and exit multinomial logit models with the addition of the HighRepVC variable. Table IX reports the firm size and profitability regressions, which are analogous to those in the top panel of Table III. In the first three specifications, we add the HighRepVC dummy in addition to the VC dummy. In the last three specifications of Table IX, we also interact the HighRepVC dummy with our TimefromVC variables to examine whether having a high reputation VC firm as an investor affect the growth pattern of VCfinanced firms. We see that having a high reputation $\mathrm{VC}$ as an investor is correlated with larger VC-financed firm size, both in terms of employment and sales, and lower profitability. VCfinanced firms with high reputation investors having larger employment almost immediately relative to other VC-financed firms. However, VC-financed firms with high reputation investors do not initially exhibit higher levels of sales, but they do so eventually as the years progress from their first receiving VC financing. Further, the lower average profitability of VC-financed firms with high reputation investors increases over time, as is evidenced by the positive coefficient on the TimefromVC*HighRepVC variable in the final profitability regression. Table IX suggests that high reputation VCs make somewhat different kinds of investments relative to the average VC firm. Relative to other VC firms, VC-financed firms financed by high reputation VCs are even larger and even less profitable than the average VC-financed firm. However, the basic patterns of VC- versus non-VC financed firms, that VC firms care about scale and make investments that are generally larger and less profitable than non-VC-financed firms is true in

\footnotetext{
${ }^{11}$ We find our results are robust to alternative measures of VC reputation such as number of past deals and number of past IPOs of the VC firm. We choose to report the results using VC age for sake of brevity.
} 
general for the average VC firm, and is not driven simply by high (low) reputed VC-financed firms.

In Table X we examine whether the exit dynamics of VC-financed firms with high reputation investors differ from the average VC-financed firm. The first multinomial logit model adds the HighRepVC dummy alongside the VC dummy. We see that VC-financed firms with high reputation investors do not have statistically different average failure or acquisition rates, but that they do have higher IPO rates. This is consistent with the notion that high reputation VCs earn higher returns by investing in companies that are more likely to go public, the most profitable exit route over our sample period.

When we allow for differences in the exit dynamics by including the TimefromVC*HighRepVC and TimefromVC^ $2 *$ HighRepVC variables in the second model of Table X, a more nuanced picture emerges. We see that VC-financed firms backed by high reputation VC firms have slightly different failure dynamics, although their average probability of failure relative to the average VC-financed firms is no different. Both high and low reputed VC-financed firms display similar patterns relative to non-VC financed firms.

In particular, the statistically negative coefficient on HighRepVC indicates that high reputation VC financed firms are initially, during the VC "patient” period, 2.4 percentage points less likely to fail relative to other VC-financed firms. However, the significant positive coefficient on TimefromVC*HighRepVC and the resulting marginal probability allow us to calculate that the "patient" period for high reputation VC firms is shorter that for the average VC-financed firms. After four years, rather than the VC-financed firm average of five, the marginal probability of failure for VC-financed firms with high reputation investors turns from negative to positive relative to non-VC-financed firms. VC-financed firms with high reputation investors have on average similar probabilities of failure, but there are slight differences in the dynamics of the failures.

The estimates in Table $\mathrm{X}$ suggest another way in which high reputation VC firms may earn higher returns for their investors besides investing in firms that are more likely to go public. ${ }^{12}$ In particular, high reputation VC firms seem to wait a shorter period of time before

\footnotetext{
${ }^{12}$ Kaplan and Schoar (2005) document that some VC firms earn consistently higher returns than others and that older VC firms are more likely to outperform younger VC firms.
} 
recognizing their failed investments. The saved opportunity cost of this invested capital could also contribute to high reputation VC firms’ higher returns.

In Table XI, we examine whether VC-financed firms with high reputation investors look on average different from other VC-financed firms at failure. We find that they do not look significantly different in terms of sales and profitability, though they do have slightly more employees. This suggests that high reputation VCs are making similar shut down decisions as other VC firms, however, they able to do so faster by perhaps investing more quickly in the companies they back. Importantly, both low reputed and high reputed VCs differ in the same way from non-VC financed firms. This suggests that the basic patterns of VC- versus non-VC financed firms we have uncovered in the previous sections are not being driven by certain kinds of venture capitalists, in particular, by high (low) reputed VC firms.

\section{Conclusion}

This paper is the first to our knowledge that uses a panel data set of the universe of employer firms in the U.S. over two decades in conjunction with other government and proprietary data sources to empirically examine the lifecycle dynamics of VC-financed and nonVC-financed firms. Using the universe of firms across different industries and geographic areas as well as a matched sample of VC- and non-VC-financed firms, we explore differences in VC and non-VC-financed firms in order address some important questions. Specifically, we ask to what firm-level and market-wide characteristics venture capitalists respond in making their investments. On the firm level, we find that venture capitalists disproportionately invest in firms that have no commercial sales, but which exhibit high levels of initial investment. Further, VCfinanced firms are larger than non-VC-financed firms, as measured by employment and sales at every point along the lifecycle, suggesting that scale of investment and production is an important criterion in VC financing. In our matched sample of firms, we observe that after receiving VC, VC-financed firms exhibit larger levels of investment in employment relative to the matched non-VC-financed firms. VC-financed firms also exhibit larger levels of sales but their expenditures increase correspondingly so that VC-financed firms are no more profitable than the non-VC-financed firms before they are exited. These results speak to the importance of scale in VC financing and also suggest VC is 'patient' money. 
To examine this conjecture more closely, we analyze the exit dynamics of VC- and nonVC-financed firms. We find that the cumulative failure rates, as well as the cumulative IPO and acquisition rates, of VC-financed firms are greater than that of non-VC-financed firms in both the full sample and the matched sample. However, the failure dynamics of VC-financed firms in the matched sample are nuanced - VC is patient in the first five years with lower rates of failure rates, but the longer term probability of failure is higher. We do not find evidence that these results are being driven by VC failures being disguised as acquisitions or different thresholds for failure of VC and non-VC financed firms. Nor do we find that different types of VC firms are driving the results.

Our analysis of a large panel data set that contains both VC- and non-VC-financed firms allows us to distill some fundamental facts on VC financing, how it responds to firm-level and market-level characteristics, and on the exit dynamics of VC-financed firms. These facts can inform both future theoretical and empirical work that attempts to understand further why firms use VC, which firms venture capitalists choose to back, or how venture capitalists influence firms' outcomes. Overall our findings suggest that a primary role played by VC is to keep firms alive in the early part of their lifecycles and give them a chance to grow and reach the critical thresholds for successful exit. However, this initial period of patience and growth comes with a cost. Conditional on surviving past a certain point in time, VC-financed firms have a higher marginal probability of failure relative to non-VC-financed firms that have survived over the same time.

Our findings also raise a number of future research questions. For example, while VC appears to have had a positive effect on firms over the past two decades, have the ways that VC helps the performance of firms changed over time? If so, is this due to improved financial contracting or due to other interactive effects of VC? 


\section{Appendix A: Matching VentureXpert to the Longitudinal Business Database}

This appendix describes how we match VentureXpert to the LBD in order to identify VCfinanced firms in the LBD. Our matching algorithm begins with the set of firms in the LBD in 2001 and works backwards in time through the LBD for each successive matching attempt. We begin by trying to match our VentureXpert firms to the LBD by using the full company name and address, i.e., name, city, state and zip code. If a firm in VentureXpert matches to multiple firms in the LBD, we use the match which has the smallest difference between the first LBD year and the VentureXpert founding date, or the first VC financing date if VentureXpert does not report the firm's founding date. ${ }^{13}$ After matching on full name and address from 2001 to 1975, we then match on full name and partial address, i.e., state and zip code only, then state and city only, then state only, again eliminating multiple matches by using the match with the smallest difference between the first LBD year the VentureXpert founding year of first year of VC financing. We then match on partial name, i.e., a substring of the full name of the first $\mathrm{N}$ characters, and full address and then partial name and partial address, again eliminating multiple matches by using the match with the smallest difference between the first LBD year and the VentureXpert founding year or first VC financing year.

Our matching algorithm yields 16,109 matches, for a raw match rate of 16,109/21,702 = 74\%. Because we do not restrict our sample of VentureXpert companies based on founding year or the date of first VC financing, there are some companies in our VentureXpert extract that likely should not be matched to the LBD if these companies either get acquired or shut down prior to 1975 or do not enter the LBD until after 2001. Because we cannot identify these companies precisely, i.e. because VentureXpert does not always report the company's founding date and does not tell us when these companies begin or stop reporting positive employment or payroll, we can only estimate the number of such companies in our VentureXpert extract. Out of our 5,593 unmatched companies in VentureXpert we estimate that about 25\% were started after 2001. Taking this into account, we have a revised match rate of about $80 \% .{ }^{14}$ This match rate

\footnotetext{
13 The founding date is missing in about $25 \%$ of our VentureXpert firms.

${ }^{14}$ Our non-matched VentureXpert firms are randomly distributed over time and industries, which suggests that any misclassification of firms in the LBD as non-VC-financed is random, thus adding classical measurement error to our VC-financed firm indicator variables. Classical measurement error in an independent variable will attenuate
} 
does not account for firms started prior to 1975 that may have been acquired or shut down before ever entering the LBD. Therefore, our $80 \%$ match rate is a conservative match rate estimate. According to Census Bureau researchers who regularly engage in name and address matching with Census micro-datasets, our $80 \%$ match rate is as high as what other researchers using these datasets have been able to attain, given the propensity for non-standardized spellings of words and occasional misspellings that appear in administrative records data.

estimated coefficients, thus working against finding any significant differences between characteristics of VCfinanced and non-VC-financed firms in our analysis. 


\section{Appendix B: Creating a Matched Sample of VC- and non-VC-Financed}

Firms

This appendix describes how we create a matched sample of VC- and non-VC-financed firms within the LBD. We match each VC-financed firm in the LBD to a non-VC-financed firm that is in the same 4-digit SIC industry code, is the same age in the year the VC-financed firm first receives VC financing, is in the same geographical location and has the same number of employees at the time of VC financing. We obtain a one-to-one matched sample of 7,632 VCfinanced firms and 7,632 non-VC-financed firms. The number of VC-financed firms in our matched sample is smaller than the total number of VC-financed firms in the LBD reported in Table I for two main reasons. First, some firms obtain VC financing in the year or two before they enter the LBD and some firms obtain VC financing after 2001, when the current version of the LBD ends. For these firms, we are unable to observe their employment in the year of VC financing and cannot match them to non-VC-financed firms based on this criterion. Second, for some VC-financed firms we cannot find an observationally equivalent non-VC-financed firm on all four dimensions - geography, age, industry and employment size. We exclude these nonmatched VC-financed firms from our matched sample.

We also form an alternative matched sample of VC- and non-VC-financed which does not restrict use to one-for-one matching. If at least one non-VC-financed firms matches to a VCfinanced firm, and vice versa, we keep all VC- and non-VC-financed firms with the same matching criteria, so that the number of VC-financed firms for a given set of match criteria may be greater or less than the number of non-VC-financed firms with the same match criteria. This leads to an unbalanced number of VC- and non-VC-financed firms in the alternative matched sample. We find that our results are robust to analysis of this alternative matched sample. As reported in Abadie and Imbens (2006), there are tradeoffs to estimating effects with these two different matched samples. We choose to be more conservative and report results using the oneto-one matched sample.

Table XII reports the characteristics of the one-to-one matched sample on each of the four matching variables. About half of the sample is matched at age one, and one quarter is matched at age two. The rest are spread out along the age spectrum. Forty percent of the firms 
are located in California. About twelve percent each are in the New England, Mid Atlantic and South Atlantic census regions, for a total of thirty-six percent located on the east coast. ${ }^{15}$ The remaining firms are spread out in the interior of the U.S. Looking at employment size, we see that there is a lot more heterogeneity in the sizes of firms at matching than there is in their ages and geographies. The largest percentage, twenty-four, of firms have between eleven and twenty employees at matching. Between fifteen and seventeen percent of firms each fall into employment categories of 2-3, 4-6 and 7-10 at matching. Another eleven percent have between 21 and 30 employees at matching. There is then a tail of firms that have more than 30 employees at matching that trails off as employment numbers rise.

Thus, we have created a sample of VC- and non-VC-financed firms that look the same at the time the VC-financed firms first receive $\mathrm{VC}$ in terms of employment, age, industry and geography.

\footnotetext{
${ }^{15}$ The nine Census region are defined as follows: New England (ME, VT, NH, MA, CT, RI), Mid-Atlantic (NY, PA, NJ), South Atlantic (DE, MD, WV, DC, VA, NC, SC, GA, FL), East North Central (WI, MI, IL, IN, OH), East South Central (KY, TN, MS, AL), West North Central (MN, IA, MO, ND, SD, NE, KS), West South Central (AR, OK, TX, LA), Mountain (MT, ID, WY, NV, UT, CO, AZ, NM) and Pacific (WA, OR, HI, AK).
} 


\section{References}

Abadie, A. and G. Imbens, 2006, Large Sample Properties of Matching Estimators for Average Treatment Effects, Econometrica 74 (1), 235-267.

Baker, M. and P. Gompers, 1999, Executive Ownership and Control in Newly Public Firms: The Role of Venture Capitalists, Harvard Business School working paper.

Baron, J., M. Hannan and D. Burton. 1999, Building the Iron Cage: Determinants of Managerial Intensity in the Early Years of Organizations, American Sociological Review 64(4), 527-547.

Botazzi, L., T. Hellmann and M. da Rin, 2007, "Who are the active investors? Evidence from venture capital”, Journal of Financial Economics, forthcoming.

Brav, A. and P. Gompers, 1997, Myth or Reality? The Long-Run Underperformance of Initial Public Offerings: Evidence from Venture and Nonventure Capital-Backed Companies, Journal of Finance 52(5), 1791-1821.

Gompers, P., 1996 "Grandstanding in the Venture Capital Industry." Journal of Financial Economics 42, 133-156.

Gompers, P., A. Kovner, J. Lerner and D. Scharfstein, 2008, Venture Capital Investment Cycles: The Impact of Public Markets, Journal of Financial Economics 87, 1-23.

Gompers, P. and J. Lerner, 2001, "The Venture Capital Revolution," Journal of Economic Perspectives, 15, 145-168

Hellmann, T. and Puri, M., 2000, "The Interaction between Product market and Financing Strategy: The Role of Venture Capital” Review of Financial Studies, 13, 4,959-984.

Hellmann, T. and Puri, M., 2002, "Venture Capital and the Professionalization of Start-Up Firms: Empirical Evidence” Journal of Finance, 2002, 57 (1), 169-197. 
Hochberg, Y., 2005, Venture Capital and Corporate Governance in the Newly Public Firm, Northwestern University working paper.

Jarmin, R. and J. Miranda, 2002, “The Longitudinal Business Database,” CES Working Paper No. 02-17.

Kaplan, S. and A. Schoar, 2005, "Private Equity Performance: Returns, Persistence and Capital Flows,” Journal of Finance 60 (4), 1791 - 1823.

Kaplan, S. and P. Stromberg, 2004, Characteristics, Contracts, and Actions: Evidence From Venture Capitalist Analyses, Journal of Finance 59, 2177-2210.

Kaplan, S. and P. Stromberg, 2003, Financial Contracting Theory Meets the Real World: Evidence from Venture Capital Contracts, Review of Economic Studies 70, 281-315.

Kortum, S., and J. Lerner, 2000, “Assessing the contribution of Venture Capital to Innovation?” Rand Journal of Economics 31: 674-92.

Lerner, J., 1995, “Venture Capitalists and the Oversight of Private Firms,” Journal of Finance, 50:1, March, 301-318.

Lindsey, L., 2008, Blurring the Boundaries: The Role of Venture Capital in Strategic Alliances, Journal of Finance, forthcoming.

Megginson,W. and K.Weiss, 1991, Venture Capital Certification in Initial Public Offerings. Journal of Finance 46, 879-893.

Sorensen, M., 2007. How Smart is Smart money? An Empirical Two-sided Matching Model of Venture Capital. Journal of Finance 62(6), 2725 - 2762.

Zarutskie, R., 2008, The role of top management team human capital in venture capital markets: Evidence from first-time funds, Duke University working paper. 


\section{Figure 1. Average size of all VC- and non-VC-financed firms in the LBD}

The sample is comprised of all firms that enter the Longitudinal Business Database (LBD) between 1981 and 2001 and tracks them until the year of their first exit event, if applicable, via failure, acquisition or IPO. Employment and payroll data are taken from the LBD. Sales data are taken from the 1982, 1987, 1992, and 1997 waves of the Censuses of Services, Retail Trade and Wholesale Trade for firms in the services, retail trade and wholesale trade industries and from the Longitudinal Research Database (LRD) for firms in the manufacturing industries (SIC 2000-3999).

Figure 1a. Average employment for VC- and non-VC-financed firms

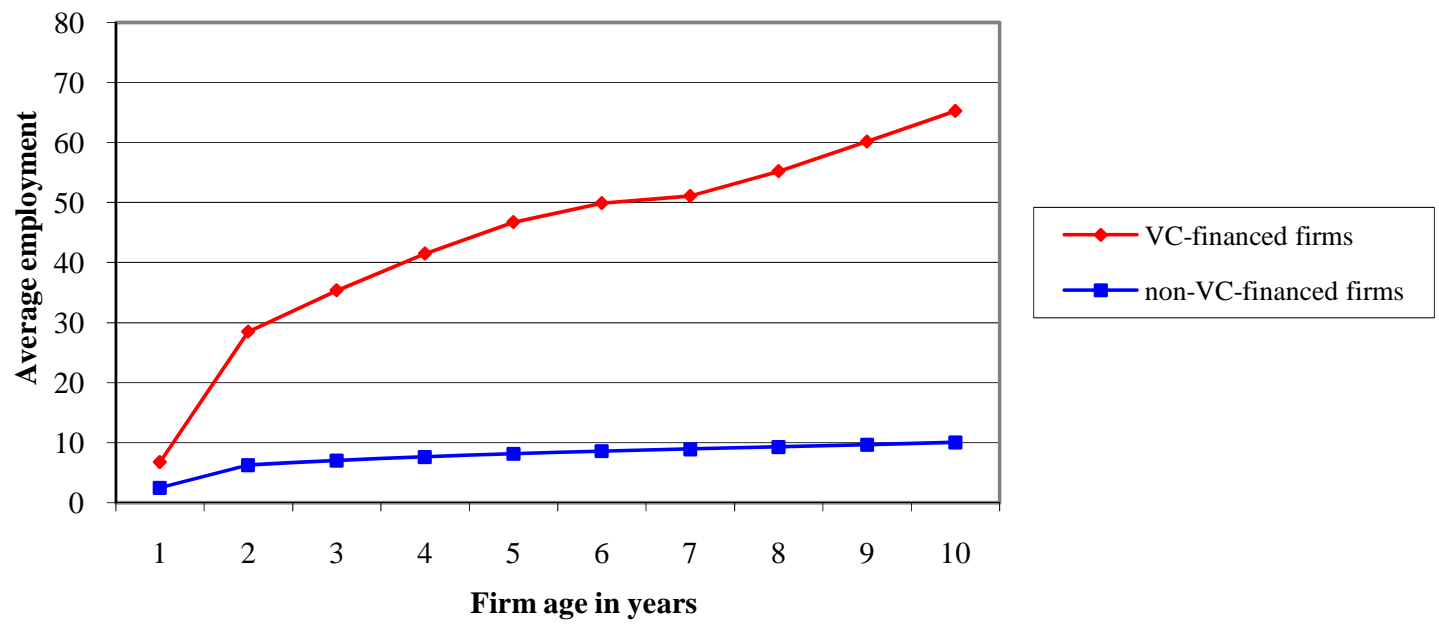

Figure 1b. Average sales for VC- and non-VC-financed firms

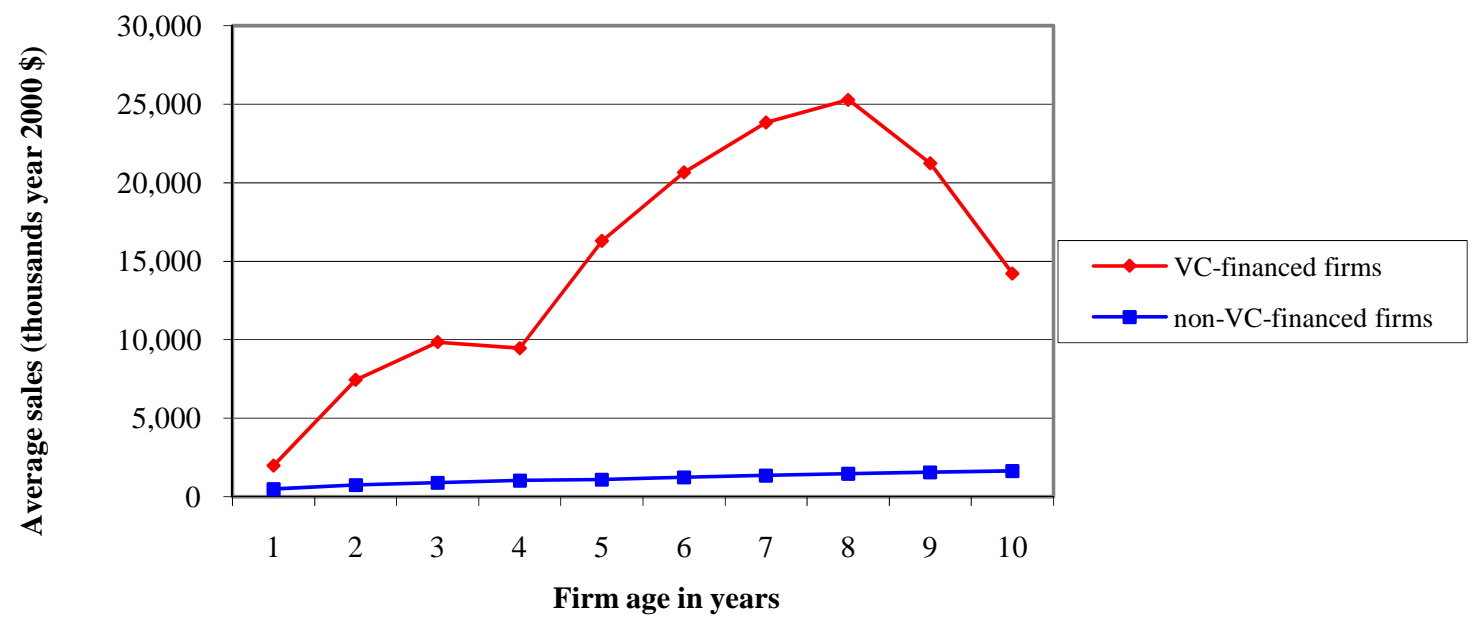


Figure 2. Average firm size and profitability in matched sample

The sample is the matched sample of 7,632 VC-financed and 7,632 non-VC-financed firms described in the Appendix. The firms are tracked from the time they enter the LBD to the year of their first exit event, if applicable, via failure, acquisition or IPO.

Employment and payroll data are taken from the LBD. Sales data are taken from the 1982, 1987, 1992, and 1997 waves of the Censuses of Services, Retail Trade and Wholesale Trade for firms in the services, retail trade and wholesale trade industries and from the Longitudinal Research Database (LRD) for firms in the manufacturing industries (SIC 2000-3999).

Figure 2a. Average employment in matched sample

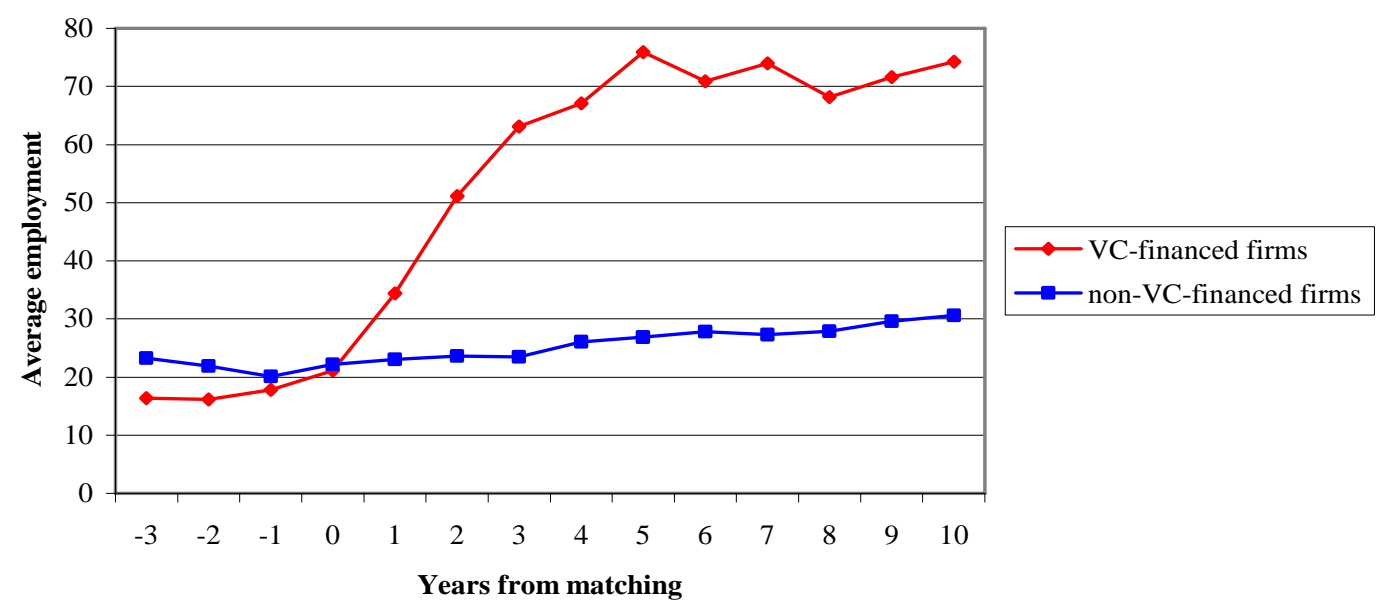

Figure 2b. Average sales for matched sample

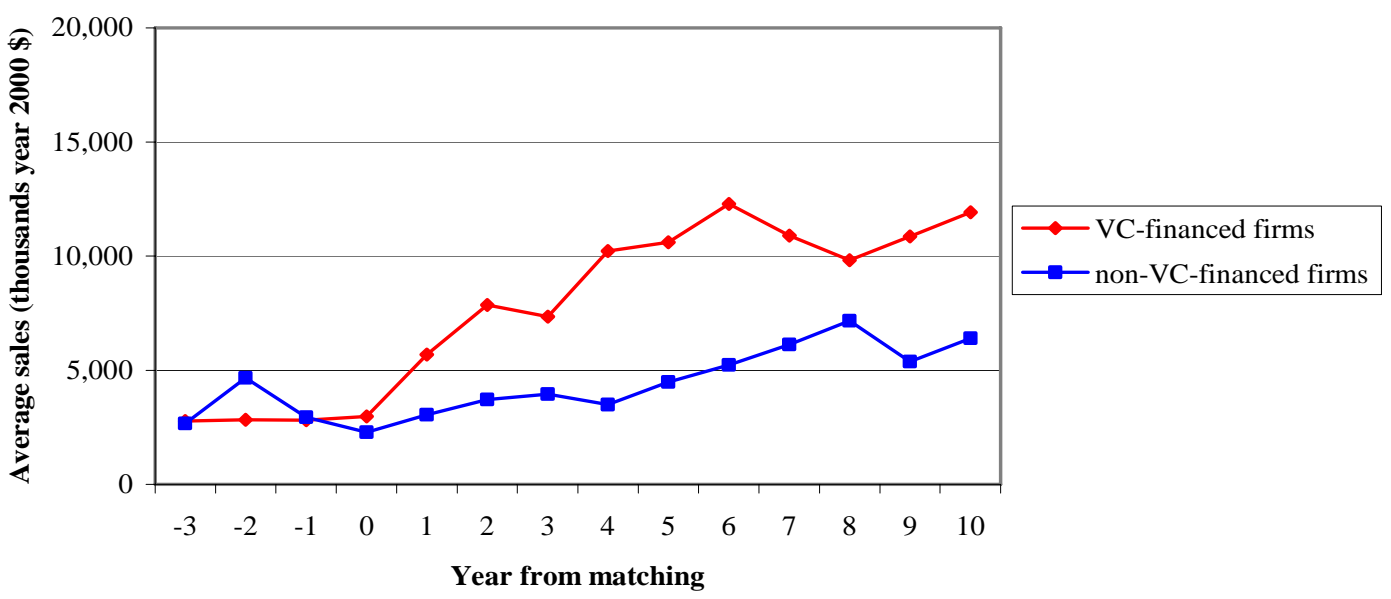

Figure 2c. Average (Sales-Payroll)/Sales in matched sample

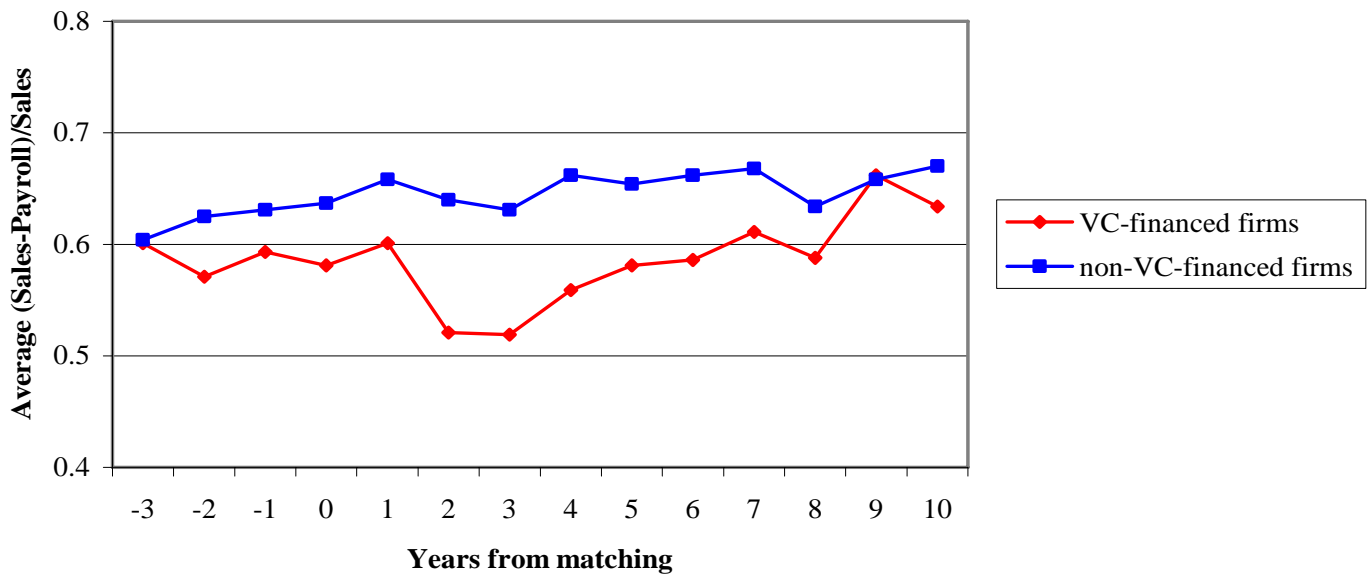




\section{Table I. Industry composition of all VC- and non-VC-financed firms in the LBD}

The sample is comprised of all firms that enter the Longitudinal Business Database (LBD) between 1981 and 2001. A firm is classified in the "Computer" industry if its primary SIC code is 3570-5379, 5044, 5045, 5734, or 7370-7379. A firm is classifed in the "Biotech/Medical" industry if its primary SIC code is 2830-2839, 3826, 3841-3851, 5047, 5048, 5122, 6324, 7352, 800-8099, or 8730-8739 excluding 8732. A firm is classified in the "Electronics" industry if its primary SIC code is 3600-3629, 3643, 3644, 3670-3699, 3825, 5065, or 5063. A firm is classified in the "Telecom" industry if its primary SIC code is 3660-3669 or 4810-4899. A firm is classified in the "Consumer" industry if its primary SIC code is 2310-2325, 2329, 2331-2342, 2360-2389, 2392, 2510-2519, 2844, 3140-3149, 3630-3639, 3931, 3942, 3944, 3946, 5023, 5064, 5091, 5092, 5094, 5136, 5137, 5139, 5140-5149, 5180, 5181, 5182, 5192, 5194, 5199, 5411, 5421, 5431, 5441, 5451, 5499, 5531, 5610-5699, 5710-5731, 5735, 5736, 5812, 5183, 5910-5963, 5992, 5993, 5994, or 5999. A firm is classified in the "Finance" industry if its primary SIC code is 6020-6062, 6090-6099, 6111-6289, 6311, 6321, 6331, 6351, 6361, 6411, 6510-6553, 6712, 6722, 6726, or 6790-6799. A firm is classified in the "Business" industry if its primary SIC code is 7310-7349 or 8710-8748. A firm is classified in the "Industrial" industry if its primary SIC code is 1311, 1381, 1382, 1389 or in a manufacturing SIC code, 2010-3999, not already used to define the previous seven industries. A firm is classified in the "Other" industry if its primary SIC code is not used to define any of the previous eight industries. Industries are selected to correspond to the industrial classifications given to VC-financed firms by VentureXpert. SIC codes are assigned to these nine industries based on the observed mapping of VC-financed firms' VentureXpert industry classifications to their primary SIC codes in the LBD. VC-financed firms are firms that receive VC financing at some point in time as identified by VentureXpert; thus some VC-financed firms first receive VC financing in a year subsequent to their entry in the LBD. Firm-level revenue data from tax returns are available from the Standard Statistical Establishment List (SSEL) between 1995 and 2001 . SSEL tax return data are missing for one third of the non-VC-financed firms and for one quarter of VC-financed firms. The last panel reports the industry composition of firms that enter the LBD between 1995 and 2001 and that reported zero revenues on their tax returns in their first year in the LBD.

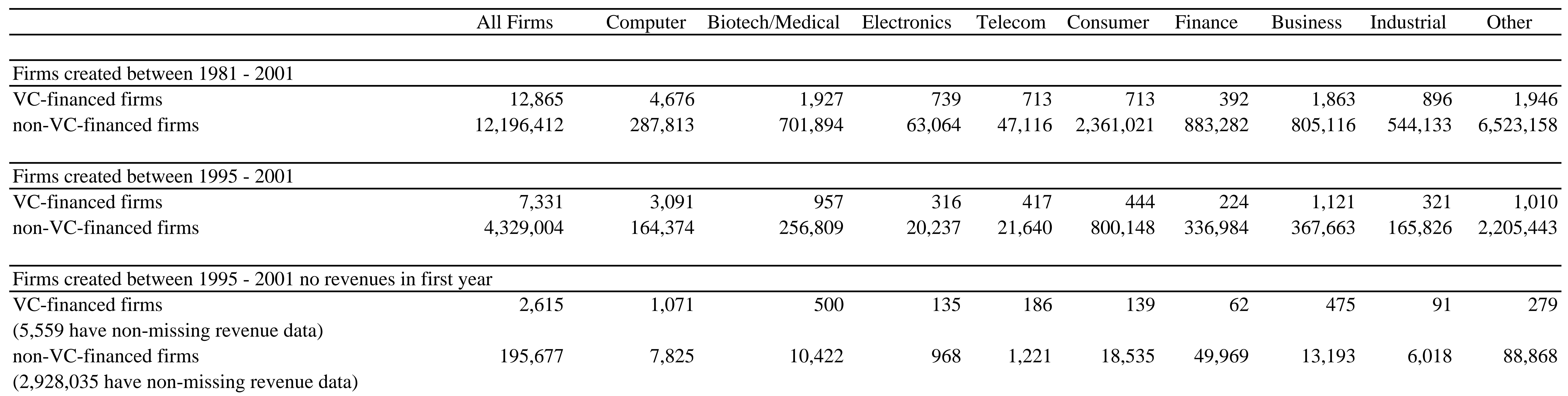


Table II. New firm creation in response to public market signals

The first three specifications in the top panel regress the natural logarithm of new firms created in an industry-year (in each of the nine industries defined in Table I in each of the 21 years in the sample period (1981-2001)) as a function of a one year lag of a public equity market investment opportunity signal in that industry as well as industry and year fixed effects. The second three specifications in the top panel regress the log odds ratio of VC- to non-VC-financed firms created in each industry-year as a function of the lagged public equity market signal as well as industry and year fixed effects. The regressions in the bottom panel weight new firms by their initial employment when forming the dependent variables measuring the log of new firms created in each industry-year and the log odds ratio of VC- to non-VC-financed firms in each industry-year. $\log (\operatorname{IPO}(-1))$ is the natural logarithm of the number of IPOs in each of the nine industries lagged by one year, taken from SDC Platinum Global New Issues database. Log(Tobin's Q(-1)) is the natural logarithm of the weighted (by market capitalization) average of the ratio of market asset value to book asset value of firms in each of the nine industries lagged by one year, taken from Compustat. Log(Market Cap(-1)) is the natural logarithm of the total equity market capitalization of firms in each of the nine industries lagged by one year, taken from Compustat. OLS regression coefficients are reported followed by t-statistics (adjusted for clustering by industry-year) in parentheses. $* * *, * *$, and * indicate statistical significance at the $1 \%, 5 \%$ and $10 \%$ levels, respectively.

\begin{tabular}{|c|c|c|c|c|c|c|}
\hline \multirow{2}{*}{$\overline{\text { Panel A }}$} & \multirow{2}{*}{\multicolumn{3}{|c|}{$\begin{array}{l}\text { Log(Number of new firms) } \\
\text { in industry-year } \\
\end{array}$}} & & & \\
\hline & & & & \multicolumn{3}{|c|}{$\begin{array}{l}\text { Log odds ratio of VC- to non-VC } \\
\text { financed new firms in industry-year }\end{array}$} \\
\hline Log(IPOs (-1)) & $\begin{array}{l}0.114 * * * \\
(2.58)\end{array}$ & & & $\begin{aligned} 0.106 \\
(1.77)\end{aligned}$ & & \\
\hline Log(Tobins Q (-1)) & \multicolumn{3}{|c|}{$\begin{array}{l}0.187 * \\
(1.85)\end{array}$} & \multicolumn{3}{|c|}{$\begin{array}{l}-0.002 \\
(-0.02)\end{array}$} \\
\hline Log(Market Cap (-1)) & & & $\begin{array}{l}0.188 * * \\
(2.29)\end{array}$ & & & $\begin{array}{r}0.056 \\
(0.62)\end{array}$ \\
\hline Inudstry F.E.? & Yes & Yes & Yes & Yes & Yes & Yes \\
\hline Year F.E.? & Yes & Yes & Yes & Yes & Yes & Yes \\
\hline $\mathrm{N}$ & 189 & 189 & 189 & 189 & 189 & 189 \\
\hline $\mathrm{R} 2$ & 0.980 & 0.980 & 0.980 & 0.971 & 0.971 & 0.971 \\
\hline \multirow[t]{2}{*}{ Panel B } & & & & & & \\
\hline & \multicolumn{3}{|c|}{$\begin{array}{l}\text { Log(New firm employment) } \\
\text { in industry-year } \\
\end{array}$} & \multicolumn{3}{|c|}{$\begin{array}{l}\text { Log odds ratio of VC- to non-VC- } \\
\text { backed new firm employment in industry-year }\end{array}$} \\
\hline Log(IPOs (-1)) & $\begin{array}{l}0.186 * * * \\
(3.42)\end{array}$ & & & $\begin{array}{r}0.087 \\
(0.96)\end{array}$ & & \\
\hline Log(Tobins Q (-1)) & & $\begin{array}{l}0.256 * \\
(2.10)\end{array}$ & & & $\begin{array}{l}-0.009 \\
(-0.04)\end{array}$ & \\
\hline Log(Market Cap (-1)) & & & $\begin{array}{l}0.269 * * * \\
(2.53)\end{array}$ & & & $\begin{array}{r}0.212 \\
(1.18)\end{array}$ \\
\hline Inudstry F.E.? & Yes & Yes & Yes & Yes & Yes & Yes \\
\hline Year F.E.? & Yes & Yes & Yes & Yes & Yes & Yes \\
\hline $\mathrm{N}$ & 189 & 189 & 189 & 189 & 189 & 189 \\
\hline R2 & 0.968 & 0.966 & 0.967 & 0.912 & 0.912 & 0.912 \\
\hline
\end{tabular}


Table III. Matched sample firm size and profitability regressions

The sample is the matched sample of 7,632 VC-financed and 7,632 non-VC-financed firms described in the Appendix. The sample tracks firms from year of matching to the year of their first exit event, if applicable, via failure, acquisition or IPO. Employment and payroll data are taken from the LBD. Sales data are taken from the 1982, 1987, 1992, and 1997 waves of the Censuses of Services, Retail Trade and Wholesale Trade for firms in the services, retail trade and wholesale trade industries and from the Longitudinal Research Database (LRD) for firms in the manufacturing industries. Firm sales (reported in thousands of year 2000 dollars) is rarely equal to zero, but rather equal to a very small positive number, in the Census waves and LRD. Note that the large number of missing firm-years in the $\log$ (Sales) regressions is due to the fact that we only observe sales data in five year intervals, if at all, for all industries except manufacturing industries (SIC 2000-3999). Return on sales (ROS) is income divided by sales; income is defined as sales minus cost of materials minus capital expenditures minus rental payments. Note that the additional variables used to calculate income are only available in the LRD for manufacturing industries (SIC 2000-3999). VC is a dummy variable equal to one for VC-financed firms (=1 in all firm-years for VC-financed firms). TimefromVC measures time in years from the point at which a VC-financed firm first receives VC financing. TimefromMatch measures time in years from the point at which VC-financed and non-VC-financed firms are matched to each other. Note that VC-financed firms are matched to non-VC-financed firms in the year they first receive VC financing. The top panel presents OLS regression estimates using the LBD as the base estimation sample. The bottom panel presents OLS regression estimates using the LRD as the base estimation sample. Included in each regression, in addition to the reported variables, are year fixed effects, industry fixed effects (based on the nine industries defined in Table I), and the age at which firms were matched. OLS coefficients are reported followed by t-statistics (adjusted for clustering by firm) in parentheses. ***, **, and * indicate statistical significance at the $1 \%$, $5 \%$ and $10 \%$ levels, respectively.

\begin{tabular}{|c|c|c|c|c|c|c|}
\hline & \multicolumn{6}{|c|}{ LBD } \\
\hline & Log(Employment) & Log(Sales) & (Sales-Payroll)/Sales & Log(Employment) & Log(Sales) & (Sales-Payroll)/Sales \\
\hline VC & $\begin{array}{l}0.6177^{* * *} \\
(28.27)\end{array}$ & $\begin{array}{l}0.924 * * * \\
(21.70)\end{array}$ & $\begin{array}{l}-0.079 * * * \\
(-11.51)\end{array}$ & $\begin{array}{l}-0.055 * \\
(-1.79)\end{array}$ & $\begin{array}{l}0.678 * * * \\
(9.28)\end{array}$ & $\begin{array}{l}-0.077 * * * \\
(-5.75)\end{array}$ \\
\hline TimefromVC & & & & $\begin{array}{l}0.289 * * * \\
(17.49)\end{array}$ & $\begin{array}{l}0.102 * * * \\
(2.91)\end{array}$ & $\begin{array}{l}-0.008 \\
(-1.46)\end{array}$ \\
\hline TimefromVC^2 & & & & $\begin{array}{l}-0.017 * * * \\
(-11.96)\end{array}$ & $\begin{array}{l}-0.006 * * \\
(-2.08)\end{array}$ & $\begin{array}{l}0.001 * * * \\
(2.64)\end{array}$ \\
\hline TimefromMatch & $\begin{array}{l}0.159 \text { *** } \\
(21.25)\end{array}$ & $\begin{array}{l}0.210^{* * *} \\
(11.09)\end{array}$ & $\begin{array}{l}-0.008 * * * \\
(-2.61)\end{array}$ & $\begin{array}{l}0.036 * * * \\
(3.96)\end{array}$ & $\begin{array}{l}0.164 * * * \\
(6.90)\end{array}$ & $\begin{array}{l}-0.006 \\
(-1.69)\end{array}$ \\
\hline TimefromMatch $\wedge 2$ & $\begin{array}{l}-0.008^{* * *} \\
(-14.16)\end{array}$ & $\begin{array}{l}-0.010 * * * \\
(-6.53)\end{array}$ & $\begin{array}{l}0.001 * * * \\
(2.69)\end{array}$ & $\begin{array}{l}-0.001 * \\
(-1.75)\end{array}$ & $\begin{array}{l}-0.007 * * * \\
(-3.91)\end{array}$ & $\begin{array}{l}0.000 \\
(1.15)\end{array}$ \\
\hline $\begin{array}{l}\text { Industry F.E.? } \\
\text { Year F F? }\end{array}$ & Yes & Yes & Yes & Yes & Yes & Yes \\
\hline $\mathrm{N}$ & 59,452 & 8,295 & 8,295 & 59,452 & 8,295 & 8,295 \\
\hline $\mathrm{R} 2$ & 0.129 & 0.222 & 0.078 & 0.146 & 0.223 & 0.080 \\
\hline
\end{tabular}

\begin{tabular}{|c|c|c|c|c|c|c|}
\hline & \multicolumn{6}{|c|}{ LRD (Manufacturing industries only) } \\
\hline & Log(Employment) & Log(Sales) & ROS & Log(Employment) & Log(Sales) & ROS \\
\hline $\mathrm{VC}$ & $\begin{array}{l}0.460 * * * \\
(6.45)\end{array}$ & $\begin{array}{l}0.9677^{* * *} \\
(11.19)\end{array}$ & $\begin{array}{l}-0.093 * * * \\
(-3.33)\end{array}$ & $\begin{array}{l}-0.222 * * \\
(-2.07)\end{array}$ & $\begin{array}{l}0.685 * * * \\
(5.07)\end{array}$ & $\begin{array}{l}-0.149 * \\
(-2.64)\end{array}$ \\
\hline TimefromVC & & & & $\begin{array}{l}0.260 * * * \\
(5.33)\end{array}$ & $\begin{array}{l}0.129 * * * \\
(2.36)\end{array}$ & $\begin{array}{l}0.020 \\
(0.84)\end{array}$ \\
\hline TimefromVC^2 & & & & $\begin{array}{l}-0.016 * * * \\
(-4.17)\end{array}$ & $\begin{array}{l}-0.009 * * \\
(-2.29)\end{array}$ & $\begin{array}{l}-0.001 \\
(-0.54)\end{array}$ \\
\hline TimefromMatch & $\begin{array}{l}0.243 * * * \\
(9.97)\end{array}$ & $\begin{array}{l}0.217^{* * *} \\
(7.50)\end{array}$ & $\begin{array}{l}-0.018 \\
(-1.59)\end{array}$ & $\begin{array}{l}0.131 * * * \\
(4.36)\end{array}$ & $\begin{array}{l}0.168 * * * \\
(4.57)\end{array}$ & $\begin{array}{l}-0.027 * \\
(-2.20)\end{array}$ \\
\hline TimefromMatch^2 & $\begin{array}{l}-0.011 * * * \\
(-6.04)\end{array}$ & $\begin{array}{l}-0.009 * * * \\
(-4.18)\end{array}$ & $\begin{array}{l}0.002 * \\
(1.82)\end{array}$ & $\begin{array}{l}-0.004 * * \\
(-2.24)\end{array}$ & $\begin{array}{l}-0.006 * * \\
(-2.33)\end{array}$ & $\begin{array}{l}0.002 * \\
(2.39)\end{array}$ \\
\hline Industry F.E.? & Yes & Yes & Yes & Yes & Yes & Yes \\
\hline Year F.E.? & Yes & Yes & Yes & Yes & Yes & Yes \\
\hline $\mathrm{N}$ & 2,144 & 2,144 & 2,144 & 2,144 & 2,144 & 2,144 \\
\hline $\mathrm{R} 2$ & 0.326 & 0.316 & 0.093 & 0.339 & 0.318 & 0.0934 \\
\hline
\end{tabular}




\section{Table IV. Matched sample average and standard deviations of firm size and profitability}

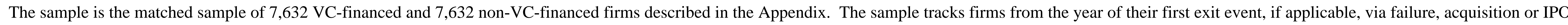
The table presents averages and standard deviations (in parentheses) of firm-level variables in years prior to, including and after being matched to an observationally equivalent VC- or non-VC-financed firm. Employment and payroll data are taken from the LBD. Sales data are taken from the 1982, 1987, 1992, and 1997 waves of the Censuses of Services, Retail Trade and Wholesale Trade for firms in the services, retail trade and wholesale trade industries and from the Longitudinal Research Database (LRD) for firms in the manufacturing industries (SIC 2000-3999). Sales data (reported in thousands of year 2000 dollars) is rarely equal to zero, but rather equal to a very small positive number, in the Census waves and LRD. $* * *, * *$, and * indicate statistical significance at the $1 \%, 5 \%$ and $10 \%$ levels, respectively.

\begin{tabular}{|c|c|c|c|c|c|c|c|c|c|c|c|c|c|c|}
\hline & \multicolumn{14}{|c|}{ Years from Matching } \\
\hline & -3 & -2 & -1 & 0 & 1 & 2 & 3 & 4 & 5 & 6 & 7 & 8 & 9 & 10 \\
\hline \multicolumn{15}{|l|}{$\overline{\text { Employment }}$} \\
\hline \multirow[t]{2}{*}{ VC-financed firms } & 16.4 & 16.2 & 17.8 & 21.1 & 34.4 & 51.1 & 63.1 & 67.1 & 75.9 & 70.9 & 74.0 & 68.2 & 71.6 & $\overline{74.3}$ \\
\hline & $(35.06)$ & (33.43) & (61.98) & (57.9) & $(57.61)$ & $(107.05)$ & (194.94) & (182.49) & (249.51) & (228.4) & (194.61) & (152.34) & $(213.41)$ & (216.49) \\
\hline \multirow[t]{2}{*}{ non-VC-financed firms } & 23.3 & 21.9 & 20.1 & 22.2 & 23.0 & 23.6 & 23.5 & 26.1 & 26.8 & 27.8 & 27.3 & 27.9 & 29.6 & 30.6 \\
\hline & (68.41) & (64.24) & (56.28) & (76.66) & (75.04) & (46.33) & (48.3) & (55.75) & (51.62) & (56.98) & $(50.84)$ & (54.06) & (58.63) & (63.27) \\
\hline \multicolumn{15}{|c|}{ Sales (thousands of year 2000 dollars) } \\
\hline \multirow[t]{2}{*}{ VC-financed firms } & $2,787.9$ & $2,841.8$ & $2,808.0$ & $2,982.1$ & $5,682.1$ & $7,870.0$ & $7,343.6$ & $10,214.2$ & $10,610.0$ & $12,293.4$ & $10,892.2$ & $9,825.4$ & $10,851.4$ & $11,912.5$ \\
\hline & $(6,288.7)$ & $(10,236.9)$ & $(6,408.4)$ & $(4,851.4)$ & $(10,712.5)$ & $(28,956.9)$ & $(11,765.9)$ & $(21,444.4)$ & $(17,415.2)$ & $(17,063.9)$ & $(16,483.9)$ & $(11,321.1)$ & $(13,587.4)$ & $(23,499.1)$ \\
\hline \multirow[t]{2}{*}{ non-VC-financed firms } & $2,660.1$ & $4,655.2$ & $2,940.4$ & $2,286.1$ & $3,043.9$ & $3,712.9$ & $3,944.6$ & $3,495.9$ & $4,475.2$ & $5,228.3$ & $6,129.9$ & $7,174.6$ & $5,368.3$ & $6,404.2$ \\
\hline & $(4,392.2)$ & $(21,680.1)$ & $(9,770.5)$ & $(4,804.4)$ & $(8,349.4)$ & $(12,919.1)$ & $(8,459.6)$ & $(6,691.2)$ & $(11,685.4)$ & $(9,511.3)$ & $(23,682.6)$ & $(20,665.8)$ & $(11,742.6)$ & $(13,735.1)$ \\
\hline \multicolumn{15}{|l|}{ (Sales-Payroll)/Sales } \\
\hline \multirow[t]{2}{*}{ VC-financed firms } & 0.601 & 0.571 & 0.593 & 0.581 & 0.601 & 0.521 & 0.519 & 0.559 & 0.581 & 0.586 & 0.611 & 0.588 & 0.662 & 0.634 \\
\hline & $(0.253)$ & $(0.274)$ & $(0.251)$ & $(0.294)$ & $(0.299)$ & $(0.314)$ & $(0.328)$ & $(0.325)$ & $(0.281)$ & $(0.264)$ & $(0.272)$ & $(0.241)$ & $(0.227)$ & $(0.245)$ \\
\hline \multirow[t]{2}{*}{ non-VC-financed firms } & 0.604 & 0.625 & 0.631 & 0.637 & 0.658 & 0.64 & 0.631 & 0.662 & 0.654 & 0.662 & 0.668 & 0.634 & 0.658 & 0.67 \\
\hline & $(0.258)$ & $(0.240)$ & $(0.248)$ & $(0.256)$ & $(0.242)$ & $(0.252)$ & $(0.250)$ & $(0.213)$ & $(0.224)$ & $(0.195)$ & $(0.200)$ & $(0.232)$ & $(0.234)$ & $(0.199)$ \\
\hline
\end{tabular}


Table V. Cumulative exit event rates for all VC- and non-VC-financed firms in the LBD

Cumulative exit event rates (reported as percentages) are reported for all VC- and non-VC-financed firms that enter the LBD between 1981 and 2001.

VC-financed firms are firms that receive VC financing at some point in time as identified by VentureXpert; thus some VC-financed firms first

receive VC financing in a year subsequent to their entry in the LBD. Firm age measures the number of years a firm is in the LBD. A firm is classified as having failed if it disappears from the LBD in its entirety, i.e. all of its establishments are shut down. A firm is classified as having been acquired if it is classified in the LBD as having an ownership change in which it becomes part of another existing firm. A firm is classified as having had an IPO if it can be matched to a firm listed as having had an IPO in the SDC Platinum Global New Issues database. The exit event which occurs first, if applicable, is the exit event assigned to a firm. Two-tailed t-statistics testing for the equality of the cumulative exit rates between VC- and non-VC-financed firms are reported at the bottom. ${ }^{* * *}, * *$, and $*$ indicate statistical significance at the $1 \%, 5 \%$ and $10 \%$ levels, respectively.

\begin{tabular}{|c|c|c|c|c|c|c|c|c|c|c|}
\hline \multicolumn{11}{|c|}{ Firm age (in years) } \\
\hline & 1 & 2 & 3 & 4 & 5 & 6 & 7 & 8 & 9 & 10 \\
\hline \multicolumn{11}{|l|}{ VC-financed firms } \\
\hline$\%$ fail & 3.45 & 7.93 & 12.16 & 15.83 & 18.99 & 21.49 & 23.33 & 24.88 & 26.16 & 26.93 \\
\hline$\%$ acquired & 1.02 & 1.95 & 2.76 & 3.52 & 4.1 & 4.67 & 5.07 & 5.48 & 5.79 & 6.03 \\
\hline$\%$ IPO & 1.53 & 2.79 & 4.61 & 6.33 & 7.58 & 8.61 & 9.35 & 9.97 & 10.47 & 10.84 \\
\hline \multicolumn{11}{|l|}{ non-VC-financed firms } \\
\hline$\%$ fail & 17.56 & 31.69 & 40.46 & 46.58 & 51.11 & 54.55 & 57.21 & 59.32 & 61.02 & 62.39 \\
\hline$\%$ acquired & 0.13 & 0.22 & 0.28 & 0.33 & 0.36 & 0.39 & 0.41 & 0.43 & 0.44 & 0.46 \\
\hline$\%$ IPO & 0.01 & 0.01 & 0.02 & 0.02 & 0.02 & 0.02 & 0.03 & 0.03 & 0.03 & 0.03 \\
\hline t-statistic for $\%$ fail & ---- & ---- & --- & ---- & $-72.51^{* * *}$ & ---- & --- & ---- & ---- & $-82.61^{* * *}$ \\
\hline t-statistic for \% acquired & ---- & ---- & ---- & ---- & $69.83^{* * *}$ & ---- & ---- & ---- & ---- & $91.89^{* * *}$ \\
\hline t-statistic for \% IPO & ---- & ---- & ---- & ---- & $530^{* * *}$ & ---- & ---- & ---- & ---- & $630^{* * *}$ \\
\hline
\end{tabular}




\section{Table VI. Cumulative exit event rates for matched sample}

The sample is the matched sample of 7,632 VC-financed and 7,632 non-VC-financed firms described in the Appendix.

Cumulative exit event rates (reported as percentages) for VC- and non-VC-financed firms from their point of being matched are reported for the entire sample period and by the three birth cohorts in Table I. A firm is classified as having failed if it disappears from the LBD in its entirety, i.e. all of its establishments are shut down. A firm is classified as having been acquired if it is classified in the LBD as having an ownership change in which it becomes part of another existing firm. A firm is classified as having had an IPO if it can be matched to a firm listed as having had an IPO in the SDC Platinum Global New Issues database. The exit event which occurs first, if applicable, is the exit event assigned to a firm. Two-tailed t-statistics testing for the equality of the cumulative exit event rates between VC- and non-VC-financed firms are reported at the bottom of each panel. ***, **, and * indicate statistical significance at the $1 \%$, $5 \%$ and $10 \%$ levels, respectively.

\begin{tabular}{|c|c|c|c|c|c|c|c|c|c|c|}
\hline & \multicolumn{10}{|c|}{ Years from Matching } \\
\hline & 1 & 2 & 3 & 4 & 5 & 6 & 7 & 8 & 9 & 10 \\
\hline \multicolumn{11}{|c|}{ Firms born 1981-2001 ( $n=7,632$ for VC-financed; $n=7,632$ for non-VC-financed) } \\
\hline \multicolumn{11}{|c|}{ VC-financed } \\
\hline$\%$ fail & 4.97 & 10.02 & 15.16 & 19.42 & 22.2 & 24.24 & 25.52 & 26.35 & 27.19 & 27.66 \\
\hline \% acquired & ---- & ---- & ---- & ---- & 3.66 & ---- & ---- & ---- & ---- & 4.81 \\
\hline$\%$ IPO & ---- & ---- & ---- & ---- & 8.12 & ---- & ---- & ---- & ---- & 10.04 \\
\hline \multicolumn{11}{|l|}{ non-VC-financed } \\
\hline$\%$ fail & 9.6 & 19.04 & 24.42 & 28.26 & 30.84 & 32.85 & 34.12 & 35.1 & 35.74 & 36.44 \\
\hline \% acquired & ---- & ---- & ---- & ---- & 1.32 & ---- & ---- & ---- & ---- & 1.45 \\
\hline$\%$ IPO & ---- & ---- & ---- & ---- & ---- & ---- & ---- & ---- & ---- & 0.37 \\
\hline t-statistic for $\%$ fail & ---- & ---- & ---- & ---- & $-12.16^{* * *}$ & ---- & ---- & ---- & ---- & $-11.67^{* * *}$ \\
\hline t-statistic for $\%$ acquired & ---- & ---- & ---- & ---- & $9.27^{* * *}$ & ---- & ---- & ---- & ---- & $11.95^{* * *}$ \\
\hline t-statistic for \% IPO & ---- & ---- & ---- & ---- & ---- & ---- & ---- & ---- & ---- & $27.62^{* * *}$ \\
\hline
\end{tabular}




\section{Table VII. Matched sample firm exit event multinomial logits}

The sample is the matched sample of 7,632 VC-financed and 7,632 non-VC-financed firms described in the Appendix. The table presents estimation output for two multinomial logit models which model exit outcomes of firms. The base outcome in both models is no exit event for the firm. A firm is classified as having failed if it disappears from the LBD in its entirety, i.e. all of its establishments are shut down. A firm is classified as having been acquired if it is classified in the LBD as having an ownership change in which it becomes part of another existing firm. A firm is classified as having had an IPO if it can be matched to a firm listed as having had an IPO in the SDC Platinum Global New Issues database. The exit event which occurs first, if applicable, is the exit event assigned to a firm. VC is a dummy variable equal to one for VC-financed firms (=1 in all firm-years for the VC-financed firm). TimefromVC measures time in years from the point at which a VC-financed firm first receives VC financing. TimefromMatch measures time in years from the point at which VC-financed and non-VC-financed firms are matched to each other. Note that VC-financed firms are matched to non-VC-financed firms in the year they first receive VC financing. Included in each multinomial logit are year fixed effects, industry fixed effects (based on the nine industries defined in Table I) and the age at which firms were matched. The models are estimated using maximum likelihood. Coefficients are reported, followed by z-statistics (adjusted for clustering by firm) in parentheses, followed by marginal probabilities (calculated at sample means) in brackets. ${ }^{* * *},{ }^{* *}$, and $*$ indicate statistical significance at the $1 \%, 5 \%$ and $10 \%$ levels, respectively.

\begin{tabular}{|c|c|c|c|c|c|c|}
\hline & \multicolumn{3}{|c|}{ Multinomial Logit \#1 (Base = No Exit) } & \multicolumn{3}{|c|}{ Multinomial Logit \#2 (Base = No Exit) } \\
\hline & Fail & Acquired & IPO & Fail & Acquired & IPO \\
\hline $\mathrm{VC}$ & $\begin{array}{c}-0.175^{* * *} \\
(-5.76) \\
{[-0.012]}\end{array}$ & $\begin{array}{l}1.506 \text { *** } \\
(13.14) \\
{[0.007]}\end{array}$ & $\begin{array}{l}3.420 * * * \\
(18.20) \\
{[0.014]}\end{array}$ & $\begin{array}{l}-1.120 * * * \\
(-12.84) \\
{[-0.068]}\end{array}$ & $\begin{array}{c}0.499 * \\
(1.81) \\
{[0.003]}\end{array}$ & $\begin{array}{r}1.580 \\
(3.77) \\
{[0.005]}\end{array}$ \\
\hline TimefromVC & & & & $\begin{array}{l}0.287 \text { *** } \\
(7.79) \\
{[0.017]}\end{array}$ & $\begin{array}{c}0.231 \text { ** } \\
(2.06) \\
{[0.001]}\end{array}$ & $\begin{array}{r}0.682 \\
(4.02) \\
{[0.002]}\end{array}$ \\
\hline TimefromVC^2 & & & & $\begin{array}{l}-0.013 \text { *** } \\
(-4.42) \\
{[-0.001]}\end{array}$ & $\begin{array}{r}-0.003 \\
(-0.38) \\
{[-6.3 e-06]}\end{array}$ & $\begin{array}{r}-0.042 \\
(-3.15) \\
{[-1.1 \mathrm{e}-04]}\end{array}$ \\
\hline TimefromMatch & $\begin{array}{l}0.5411^{* * *} \\
(29.15) \\
{[0.033]}\end{array}$ & $\begin{array}{l}0.357^{* * *} \\
(7.56) \\
{[0.001]}\end{array}$ & $\begin{array}{l}0.778 \text { *** } \\
(12.81) \\
{[0.002]}\end{array}$ & $\begin{array}{l}0.4211^{* * *} \\
(18.56) \\
{[0.025]}\end{array}$ & $\begin{array}{c}0.191 * \\
(1.90) \\
{[0.001]}\end{array}$ & $\begin{array}{r}0.138 \\
(0.87) \\
{[2.9 \mathrm{e}-04]}\end{array}$ \\
\hline TimefromMatch $\wedge 2$ & $\begin{array}{l}-0.033 \text { *** } \\
(-22.05) \\
{[-0.002]}\end{array}$ & $\begin{array}{c}-0.018 \text { *** } \\
(-5.03) \\
{[-6.1 \mathrm{e}-05]}\end{array}$ & $\begin{array}{c}-0.052 * * * \\
(-9.62) \\
{[-5.9 e-05]}\end{array}$ & $\begin{array}{l}-0.027 * * * \\
(-14.81) \\
{[-0.002]}\end{array}$ & $\begin{array}{r}-0.016 \text { * } \\
(-1.93) \\
{[-1.1 \mathrm{e}-04]}\end{array}$ & $\begin{array}{r}-0.013 \\
(-1.06) \\
{[-2.9 \mathrm{e}-05]}\end{array}$ \\
\hline $\begin{array}{l}\text { Industry F.E.? } \\
\text { Year F.E.? }\end{array}$ & $\begin{array}{l}\text { Yes } \\
\text { Yes }\end{array}$ & $\begin{array}{l}\text { Yes } \\
\text { Yes }\end{array}$ & $\begin{array}{l}\text { Yes } \\
\text { Yes }\end{array}$ & $\begin{array}{l}\text { Yes } \\
\text { Yes }\end{array}$ & $\begin{array}{l}\text { Yes } \\
\text { Yes }\end{array}$ & $\begin{array}{l}\text { Yes } \\
\text { Yes }\end{array}$ \\
\hline $\begin{array}{l}\text { N } \\
\text { Pseudo-R2 }\end{array}$ & $\begin{array}{r}66,836 \\
0.085\end{array}$ & $\begin{array}{r}66,836 \\
0.085\end{array}$ & $\begin{array}{r}66,836 \\
0.085\end{array}$ & $\begin{array}{r}66,836 \\
0.089\end{array}$ & $\begin{array}{r}66,836 \\
0.089\end{array}$ & $\begin{array}{r}66,836 \\
0.089\end{array}$ \\
\hline
\end{tabular}




\section{Table VIII. Comparing VC- and non-VC-financed firms at exit}

The sample is the matched sample of 7,632 VC-financed and 7,632 non-VC-financed firms described in the Appendix. Average values one year before an exit event (failure, acquistion and IPO) are reported for VC- and non-VC-financed firms. A firm is classified as having failed if it disappears from the LBD in its entirety, i.e. all of its establishments are shut down. A firm is classified as having been acquired if it is classified in the LBD as having an ownership change in which it becomes part of another existing firm. A firm is classified as having had an IPO if it can be matched to a firm listed as having had an IPO in the SDC Platinum Global New Issues database. The exit event which occurs first, if applicable, is the exit event assigned to a firm. Reported at the bottom of each panel are t-statistics for double-sided differences in the reported means. Employment and payroll data are taken from the LBD. Sales data are taken from the 1982, 1987, 1992, and 1997 waves of the Censuses of Services, Retail Trade and Wholesale Trade for firms in the services, retail trade and wholesale trade industries and from the Longitudinal Research Database (LRD) for firms in the manufacturing industries (SIC 2000-3999). Sales data (reported in thousands of year 2000 dollars) is rarely equal to zero, but rather equal to a very small positive number, in the Census waves and LRD. Note that the large number of missing observations in the Sales columns is due to the fact that we only observe sales data in five year intervals, if at all, for all industries except manufacturing (SIC 2000-3999). Return on sales (ROS) is income divided by sales; income is defined as sales minus cost of materials minus capital expenditures minus rental payments. Note that the additional variables used to calculate income are only availabe in the LRD for manufacturing industries (SIC 2000-3999). ***, **, and * indicate statistical significance at the $1 \%, 5 \%$ and $10 \%$ levels, respectively.

\begin{tabular}{|c|c|c|c|c|c|c|}
\hline Failures & & & & & & \\
\hline All Industries & Number & Age at Exit & $\begin{array}{l}\text { Employment } \\
\text { at Exit }\end{array}$ & $\begin{array}{l}\text { Number with } \\
\text { Sales Data }\end{array}$ & $\begin{array}{l}\text { Sales } \\
\text { at Exit }\end{array}$ & $\frac{\text { (Sales-Payroll) }}{\text { Sales }}$ \\
\hline VC-financed firms & 2,205 & 5.44 & 32.57 & 264 & $4,461.37$ & 0.64 \\
\hline non-VC-financed firms & 2,909 & 4.78 & 17.16 & 402 & $1,433.60$ & 0.70 \\
\hline t-statistic for VC vs non-VC & & $6.61^{* * * *}$ & $5.60^{* * * *}$ & & $6.91^{* * * *}$ & $-2.83^{* * * *}$ \\
\hline LRD - Manufacturing Industries & Number & Age at Exit & $\begin{array}{c}\text { Employment } \\
\text { at Exit }\end{array}$ & $\begin{array}{l}\text { Number with } \\
\text { Sales Data }\end{array}$ & $\begin{array}{l}\text { Sales } \\
\text { at Exit }\end{array}$ & $\begin{array}{l}\text { ROS } \\
\text { at Exit }\end{array}$ \\
\hline VC-financed firms & 83 & 5.82 & 32.04 & 63 & $4,758.97$ & 0.29 \\
\hline non-VC-financed firms & 103 & 5.49 & 15.43 & 78 & $2,213.20$ & 0.33 \\
\hline t-statistic & & 0.61 & $2.47^{* * *}$ & & $2.59^{* * *}$ & -0.67 \\
\hline \multicolumn{7}{|l|}{ Acquisitions } \\
\hline All Industries & Number & Age at Exit & $\begin{array}{l}\text { Employment } \\
\text { at Exit }\end{array}$ & $\begin{array}{l}\text { Number with } \\
\text { Sales Data }\end{array}$ & $\begin{array}{l}\text { Sales } \\
\text { at Exit }\end{array}$ & $\frac{\text { (Sales-Payroll) }}{\text { Sales }}$ \\
\hline VC-financed firms & 377 & 5.92 & 134.33 & 65 & $25,309.38$ & 0.61 \\
\hline non-VC-financed firms & 100 & 5.17 & 132.74 & 10 & $15,098.44$ & 0.67 \\
\hline t-statistic & & $1.66^{*}$ & 0.03 & & 0.42 & -0.58 \\
\hline \multicolumn{7}{|l|}{ IPOs } \\
\hline All Industries & Number & Age at Exit & $\begin{array}{c}\text { Employment } \\
\text { at Exit }\end{array}$ & $\begin{array}{l}\text { Number with } \\
\text { Sales Data }\end{array}$ & $\begin{array}{l}\text { Sales } \\
\text { at Exit }\end{array}$ & $\frac{\text { (Sales-Payroll) }}{\text { Sales }}$ \\
\hline VC-financed firms & 744 & 5.34 & 81.44 & ---- & ----- & ----- \\
\hline non-VC-financed firms & 22 & 5.45 & 120.77 & ---- & ----- & ---- \\
\hline t-statistic & & -0.18 & -1.07 & & & \\
\hline
\end{tabular}


Table IX. Matched sample firm size and profitability regressions with VC reputation

The sample is the matched sample of 7,632 VC-financed and 7,632 non-VC-financed firms described in the Appendix. The sample tracks firms from year of matching to the year of their first exit event, if applicable, via failure, acquisition or IPO. Employment and payroll data are taken from the LBD. Sales data are taken from the 1982, 1987, 1992, and 1997 waves of the Censuses of Services, Retail Trade and Wholesale Trade for firms in the services, retail trade and wholesale trade industries and from the Longitudinal Research Database (LRD) for firms in the manufacturing industries (SIC 2000-3999). Sales data (reported inthousands of year 2000 dollars) is rarely equal to zero, but rather equal to a very small positive number, in the Census waves and the LRD. Note that the large number of missing firm-years in the Log(Sales) regressions is due to the fact that we only observe sales data in five year intervals, if at all, for all industries except manufacturing (SIC 2000-3999). VC is a dummy variable equal to one for VC-financed firms (=1 in all firm-years for VC-financed firms). HighRepVC is a dummy equal to one for VC-financed firms whose oldest VCs in their first rounds of financing are in the top quartile of the VC age distribution. TimefromVC measures time in years from the point at which a VC-financed firm first receives VC financing. TimefromMatch measures time in years from the point at which VC-financed and non-VC-financed firms are matched to each other. Note that VC-financed firms are matched to non-VC-financed firms in the year they first receive VC financing. Included in each regression, in addition to the reported variables, are year fixed effects, industry fixed effects (based on the nine industries defined in Table I), and the age at which firms were matched. OLS regression coefficients are reported and t-statistics (adjusted for clustering by firm) are reported in parentheses. ${ }^{* * *}, * *$, and * indicate statistical significance at the $1 \%, 5 \%$ and $10 \%$ levels, respectively.

\begin{tabular}{|c|c|c|c|c|c|c|}
\hline \multicolumn{7}{|c|}{ LBD } \\
\hline $\log ($ & iployment) & Log(Sales) & (Sales-Payroll)/Sales & Log(Employment) & Log(Sales) & (Sales-Payroll)/Sales \\
\hline $\mathrm{VC}$ & $\begin{array}{l}0.572 \text { *** } \\
(22.96)\end{array}$ & $\begin{array}{l}0.903 \text { *** } \\
(18.94)\end{array}$ & $\begin{array}{l}-0.067 * * * \\
(-8.98)\end{array}$ & $\begin{array}{l}-0.063 * \\
(-1.91)\end{array}$ & $\begin{array}{l}0.734 \text { *** } \\
(8.99)\end{array}$ & $\begin{array}{l}-0.080 \text { *** } \\
(-5.35)\end{array}$ \\
\hline HighRepVC & $\begin{array}{l}0.265^{* * *} \\
(6.56)\end{array}$ & $\begin{array}{l}0.189 * * * \\
(2.60)\end{array}$ & $\begin{array}{l}-0.050 * * * \\
(-2.67)\end{array}$ & $\begin{array}{l}0.188^{* * *} \\
(2.57)\end{array}$ & $\begin{array}{l}0.004 \\
(0.03)\end{array}$ & $\begin{array}{l}0.008 \\
(0.22)\end{array}$ \\
\hline TimefromVC^2 & & & & $\begin{array}{l}-0.016 * * * \\
(-11.91)\end{array}$ & $\begin{array}{l}-0.003 \\
(-1.01)\end{array}$ & $\begin{array}{l}0.001 \\
(1.50)\end{array}$ \\
\hline TimefromVC*HighRepVC & & & & $\begin{array}{r}0.031 \\
(0.75)\end{array}$ & $\begin{array}{l}0.122 * \\
(1.72)\end{array}$ & $\begin{array}{l}-0.024 \\
(-1.60)\end{array}$ \\
\hline TimefromMatch $\wedge 2$ & $\begin{array}{l}-0.007 \text { *** } \\
(-12.38)\end{array}$ & $\begin{array}{l}-0.009 * * * \\
(-5.84)\end{array}$ & $\begin{array}{l}0.000 * * \\
(2.16)\end{array}$ & $\begin{array}{l}-0.001 \\
(-1.56)\end{array}$ & $\begin{array}{l}-0.007 * * * \\
(-3.83)\end{array}$ & $\begin{array}{r}0.000 \\
(1.02)\end{array}$ \\
\hline Industry F.E.? & Yes & Yes & Yes & Yes & Yes & Yes \\
\hline Year F.E.? & Yes & Yes & Yes & Yes & Yes & Yes \\
\hline $\mathrm{N}$ & 53,492 & 7,572 & 7,572 & 53,492 & 7,572 & 7,572 \\
\hline R2 & 0.128 & 0.221 & 0.076 & 0.144 & 0.223 & 0.078 \\
\hline
\end{tabular}


Table X. Matched sample firm exit event multinomial logits with VC reputation

The sample is the matched sample of 7,632 VC-financed and 7,632 non-VC-financed firms described in the Appendix. The table presents estimation output for two multinomial logit models which model exit outcomes of firms. The base outcome in both models is no exit event for the firm. A firm is classified as having failed if it disappears from the LBD in its entirety, i.e. all of its establishments are shut down. A firm is classified as having been acquired if it is classified in the LBD as having an ownership change in which it becomes part of another existing firm. A firm is classified as having had an IPO if it can be matched to a firm listed as having had an IPO in the SDC Platinum Global New Issues database. The exit event which occurs first, if applicable, is the exit event assigned to a firm. VC is a dummy variable equal to one for VC-financed firms (=1 in all firm-years for VC-financed firms). HighRepVC is a dummy equal to one for VC-financed firms whose oldest VCs in their first rounds of financing are in the top quartile of the VC age distribution. TimefromVC measures time in years from the point at which a VC-financed firm first receives VC financing. TimefromMatch measures time in years from the point at which VC-financed and non-VC-financed firms are matched to each other. Note that VC-financed firms are matched to non-VC-financed firms in the year they first receive VC financing. Included in each multinomial logit are year fixed effects, industry fixed effects (based on the nine industries defined in Table I) and the age atwhich firms were matched. The models are estimated using maximum likelihood.

Coefficients are reported, followed by z-statistics (adjusted for clustering by firm) in parentheses, followed by marginal probabilities (calculated at sample means) in brackets. ${ }^{* * *},{ }^{* *}$, and ${ }^{*}$ indicate statistical significance at the $1 \%, 5 \%$ and $10 \%$ levels, respectively.

\begin{tabular}{|c|c|c|c|c|c|c|}
\hline & \multicolumn{3}{|c|}{ Multinomial Logit \#1 (Base = No Exit) } & \multicolumn{3}{|c|}{ Multinomial Logit \#2 (Base = No Exit) } \\
\hline & Fail & Acquired & IPO & Fail & Acquired & IPO \\
\hline $\mathrm{VC}$ & $\begin{array}{l}-0.185 * * * \\
(-4.14) \\
{[-0.010]}\end{array}$ & $\begin{array}{l}1.533^{* * *} \\
(12.78) \\
{[0.008]}\end{array}$ & $\begin{array}{l}3.35 \text { *** } \\
(17.61) \\
{[0.014]}\end{array}$ & $\begin{array}{l}-0.9888^{* * *} \\
(-9.65) \\
{[-0.058]}\end{array}$ & $\begin{array}{c}0.586 * * \\
(1.98) \\
{[0.003]}\end{array}$ & $\begin{array}{c}1.63 \text { *** } \\
(3.79) \\
{[0.005]}\end{array}$ \\
\hline HighRepVC & $\begin{array}{r}-0.017 \\
(-0.28) \\
{[-0.001]}\end{array}$ & $\begin{array}{r}0.066 \\
(0.47) \\
{[2.3 e-04]}\end{array}$ & $\begin{array}{l}0.303^{* * *} \\
(3.13) \\
{[0.001]}\end{array}$ & $\begin{array}{c}-0.465 * * \\
(-2.15) \\
{[-0.024]}\end{array}$ & $\begin{array}{c}-0.815^{* *} \\
(-1.97) \\
{[-0.002]}\end{array}$ & $\begin{array}{r}0.008 \\
(0.02) \\
{[1.0 \mathrm{e}-04]}\end{array}$ \\
\hline TimefromVC & & & & $\begin{array}{l}0.2488^{* * *} \\
(5.81) \\
{[0.015]}\end{array}$ & $\begin{array}{r}0.192 \\
(1.62) \\
{[0.001]}\end{array}$ & $\begin{array}{l}0.632 \text { *** } \\
(3.62) \\
{[0.001]}\end{array}$ \\
\hline TimefromVC^2 & & & & $\begin{array}{l}-0.0111^{* * *} \\
(-3.13) \\
{[-0.001]}\end{array}$ & $\begin{array}{r}0.000 \\
(0.01) \\
{[0.000]}\end{array}$ & $\begin{array}{c}-0.038 \text { *** } \\
(-2.77) \\
{[-8.5 \mathrm{e}-05]}\end{array}$ \\
\hline TimefromVC*HighRepVC & & & & $\begin{array}{c}0.198 * * \\
(2.23) \\
{[0.012]}\end{array}$ & $\begin{array}{l}0.612 \text { *** } \\
(3.50) \\
{[0.002]}\end{array}$ & $\begin{array}{r}0.111 \\
(0.61) \\
{[2.0 \mathrm{e}-04]}\end{array}$ \\
\hline TimefromVC^2*HighRepVC & & & & $\begin{array}{c}-0.016 \text { ** } \\
(-2.10) \\
{[-0.001]}\end{array}$ & $\begin{array}{l}-0.068 * * * \\
(-3.77) \\
{[-0.000]}\end{array}$ & $\begin{array}{r}-0.007 \\
(-0.44) \\
{[-1.2 \mathrm{e}-05]}\end{array}$ \\
\hline TimefromMatch & $\begin{array}{l}0.525 * * * \\
(27.08) \\
{[0.033]}\end{array}$ & $\begin{array}{l}0.348 \text { *** } \\
(6.69) \\
{[0.001]}\end{array}$ & $\begin{array}{l}0.723 \text { *** } \\
(10.67) \\
{[0.001]}\end{array}$ & $\begin{array}{l}0.423 * * * \\
(18.54) \\
{[0.026]}\end{array}$ & $\begin{array}{c}0.161 * \\
(1.93) \\
{[0.001]}\end{array}$ & $\begin{array}{r}0.115 \\
(0.73) \\
{[1.9 \mathrm{e}-04]}\end{array}$ \\
\hline 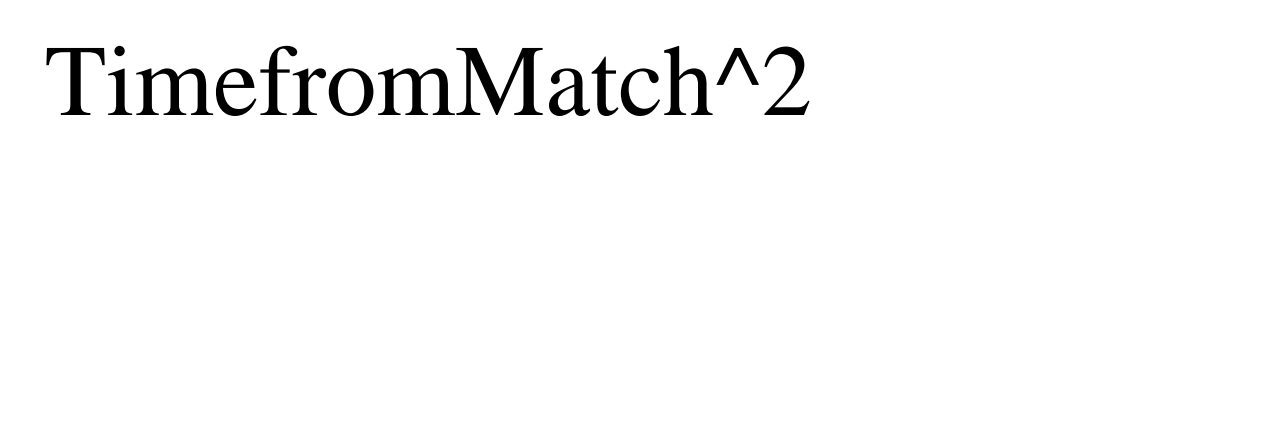 & $\begin{array}{l}-0.032 \text { *** } \\
(-20.73) \\
{[-0.002]}\end{array}$ & $\begin{array}{c}-0.018 \text { *** } \\
(-4.58) \\
{[-5.9 \mathrm{e}-05]}\end{array}$ & $\begin{array}{c}-0.049 * * * \\
(-8.09) \\
{[-9.1 \mathrm{e}-05]}\end{array}$ & $\begin{array}{l}-0.027 \text { *** } \\
(-14.81) \\
{[-0.002]}\end{array}$ & $\begin{array}{c}-0.014 * \\
(-1.70) \\
{[-5.4 \mathrm{e}-05]}\end{array}$ & $\begin{array}{r}-0.012 \\
(-0.96) \\
{[-2.2 \mathrm{e}-05]}\end{array}$ \\
\hline $\begin{array}{l}\text { Industry F.E.? } \\
\text { Year F.E.? }\end{array}$ & $\begin{array}{l}\text { Yes } \\
\text { Yes }\end{array}$ & $\begin{array}{l}\text { Yes } \\
\text { Yes }\end{array}$ & $\begin{array}{l}\text { Yes } \\
\text { Yes }\end{array}$ & $\begin{array}{l}\text { Yes } \\
\text { Yes }\end{array}$ & $\begin{array}{l}\text { Yes } \\
\text { Yes }\end{array}$ & $\begin{array}{l}\text { Yes } \\
\text { Yes }\end{array}$ \\
\hline $\begin{array}{l}\mathrm{N} \\
\text { Pseudo-R2 }\end{array}$ & $\begin{array}{r}59,270 \\
0.083\end{array}$ & $\begin{array}{r}59,270 \\
0.083\end{array}$ & $\begin{array}{r}59,270 \\
0.083\end{array}$ & $\begin{array}{r}59,270 \\
0.088\end{array}$ & $\begin{array}{r}59,270 \\
0.088\end{array}$ & $\begin{array}{r}59,270 \\
0.088\end{array}$ \\
\hline
\end{tabular}


Table XI. Comparing high and low reputation VC-financed firms at exit

The sample is the matched sample of 7,632 VC-financed and 7,632 non-VC-financed firms described in the Appendix. Average values one year before an exit event (failure, acquistion and IPO) are reported for VC- and non-VC-financed firms. A firm is classified as having failed if it disappears from the LBD in its entirety, i.e. all of its

establishments are shut down. A firm is classified as having been acquired if it is classified in the LBD as having an ownership change in which it becomes part of another existing firm. A firm is classified as having had an IPO if it can be matched to a firm listed as having had an IPO in the SDC Platinum Global New Issues database. The exit event which occurs first, if applicable, is the exit event assigned to a firm. Reported at the bottom of each panel are t-statistics for double-sided differences in the reported means. Employment and payroll data are taken from the LBD. Sales data are taken from the 1982, 1987, 1992, and 1997 waves of the Censuses of Services, Retail Trade and Wholesale Trade for firms in the services, retail trade and wholesale trade industries and from the Longitudinal Research Database (LRD) for firms in the manufacturing industries (SIC 2000-3999). Sales data (reported in thousands of year 2000 dollars) is rarely equal to zero, but rather equal to a very small positive number, in the Census waves and LRD. Note that the large number of missing observations in the Sales columns is due to the fact that we only observe sales data in five year intervals, if at all, for all industries except manufacturing (SIC 2000-3999). Return on sales (ROS) is income divided by sales; income is defined as sales minus cost of materials minus capital expenditures minus rental payments. HighRepVC is a dummy equal to one for VC-financed firms whose oldest VCs in their first rounds of financing are in the top quartile of the VC age distribution. LowRepVC is equal to 1 -HighRepVC. ${ }^{* * *}$, **, and $*$ indicate statistical significance at the $1 \%, 5 \%$ and $10 \%$ levels, respectively.

\section{Failures}

All Industries

Number

Employment

Number with

Sales

(Sales-Payroll)

LowRepVC

HighRepVC

non-VC-financed firms

$1,379 \quad 5.65$

349

5.30

at Exit

Sales Data

at Exit

Sales

t-statistic for LowRepVC vs HighRepVC

t-statistic for LowRepVC vs non-VC-financed

28.73

184

17.16

$4,332.41-0.63$
$5,832.02-0.67$

$1.63-2.87$

$402 \quad 1,433.60 \quad 0.70$

t-statistic for HighRepVC vs non-VC-financed

$\begin{array}{cc}1.63 & 2.87^{* * *} \\ -7.39^{* * *} & -6.08^{* * *} \\ -2.58 * *\end{array}$

$-2.58 * * \quad-6.55 * *$

$-1.05 \quad-0.79$

$6.45^{* * *} \quad-2.97 * * *$

$6.41 * * * \quad-0.74$

\begin{tabular}{|c|c|c|c|c|c|c|}
\hline \\
\hline $\begin{array}{l}\text { Acquisitions } \\
\text { All Industries }\end{array}$ & Number & Age at Exit & $\begin{array}{l}\text { Employment } \\
\text { at Exit }\end{array}$ & $\begin{array}{l}\text { Number with } \\
\text { Sales Data }\end{array}$ & $\begin{array}{l}\text { Sales } \\
\text { at Exit }\end{array}$ & $\frac{\text { (Sales-Payroll) }}{\text { Sales }}$ \\
\hline LowRepVC & 245 & 6.37 & 124.65 & ---- & ---- & ---- \\
\hline HighRepVC & 67 & 4.39 & 163.93 & ---- & ---- & ---- \\
\hline non-VC-financed firms & 100 & 5.17 & 132.74 & ---- & ---- & ---- \\
\hline t-statistic for LowRepVC vs HighRepVC & & $3.88 * * *$ & -0.61 & & & \\
\hline t-statistic for LowRepVC vs non-VC-financed & & $3.46 * * *$ & -0.18 & & & \\
\hline t-statistic for HighRepVC vs non-VC-financed & & -1.28 & 0.36 & & & \\
\hline
\end{tabular}

\section{IPOS}

All Industries

Age at Exit Emp

ployme

Number with

Sales (Sales-Payroll)

LowRepVC

HighRepVC

non-VC-financed firms

$428 \quad 5.56$

at Exit

Sales Data

Sales

t-statistic for LowRepVC vs HighRepVC

t-statistic for LowRepVC vs non-VC-financed

$143 \quad 5.19$

76.21

$---$

$---$

t-statistic for HighRepVC vs non-VC-financed

$----$

$----$

$1.27-2.19 * *$

$0.16-1.66$ 
Table XII. Characteristics of matched sample of VC- and non-VC-financed firms

The sample includes VC-financed firms that enter the Longitudinal Business Database between 1981 and 2001, that first receive VC financing in the year they enter the LBD or in any subsequent year up to and including 2001 and that can be matched to a non-VC-financed firm that is of the same age as the VC-financed firm in the year in which the VC-financed firm first receives VC financing, that is in the same 4 digit SIC code as the VC-financed firm, that is in the same geographical region as the VC-financed firm and that is in the same employment size category as the VC-financed firm in the year the VC-financed firm first receives VC financing. The sample also includes the matched non-VC-financed firms. The sample contains 15,264 firms; 7,632 are VC-financed and 7632 are non-VC-financed. The number and percentage of firms in the sample that are matched at a particular age, employment size category and geographical region are reported.

Firm age measures the number of years a firm is in the LBD. A firm's headquarter's geographical region is defined as follows. New England is defined by the states ME, VT, NH, MA, CT and RI. Mid Atlantic is defined by the states NY, PA and NJ. South Atlantic is defined by the statesDE, MD, WV, DC, VA, NC, SC, GA and FL. East North Central is defined by the states WI, MI, IL, IN and OH. East South Central is defined by the states KY, TN, MS and AL. West North Central isdefined by the states MN, IA, MO, ND, SD, NE and KS. West South Central is defined by the states AR, OK, TX and LA. Mountain is defined by the states MT, ID, WY, NV, UT, CO, AZ and NM. Pacific Northwest is defined by the states OR and WA.

\begin{tabular}{|c|c|c|}
\hline & Number & Percentage \\
\hline \multicolumn{3}{|l|}{ Firm age at Matching } \\
\hline 1 & 7,174 & $47 \%$ \\
\hline 2 & 3,588 & $24 \%$ \\
\hline 3 & 1,670 & $11 \%$ \\
\hline 4 & 914 & $6 \%$ \\
\hline 5 & 572 & $4 \%$ \\
\hline 6 & 330 & $2 \%$ \\
\hline 7 & 278 & $2 \%$ \\
\hline 8 & 160 & $1 \%$ \\
\hline 9 & 138 & $1 \%$ \\
\hline 10 & 92 & $1 \%$ \\
\hline$>10$ & 348 & $2 \%$ \\
\hline \multicolumn{3}{|c|}{ Number of Employees at Matching } \\
\hline $2-3$ & 2,528 & $17 \%$ \\
\hline $4-6$ & 2,318 & $15 \%$ \\
\hline $7-10$ & 2,532 & $17 \%$ \\
\hline $11-20$ & 3,708 & $24 \%$ \\
\hline $21-30$ & 1,624 & $11 \%$ \\
\hline $31-50$ & 1,362 & $9 \%$ \\
\hline $51-70$ & 410 & $3 \%$ \\
\hline $71-100$ & 296 & $2 \%$ \\
\hline $101-300$ & 436 & $3 \%$ \\
\hline$>300$ & 50 & $0 \%$ \\
\hline \multicolumn{3}{|c|}{ Firm's Geographical Region } \\
\hline California & 6,124 & $40 \%$ \\
\hline New England & 1,930 & $13 \%$ \\
\hline Mid Atlantic & 1,840 & $12 \%$ \\
\hline South Atlantic & 1,804 & $12 \%$ \\
\hline East North Central & 790 & $5 \%$ \\
\hline East South Central & 156 & $1 \%$ \\
\hline West North Central & 438 & $3 \%$ \\
\hline West South Central & 942 & $6 \%$ \\
\hline Mountain & 716 & $5 \%$ \\
\hline Pacific Northwest & 524 & $3 \%$ \\
\hline
\end{tabular}

